\title{
INOVACIJE KAO TEMELJ KONKURETNOSTI HRVATSKE PREHRAMBENE INDUSTRIJE
}

\author{
Dragan Kovačević
}

\begin{abstract}
Sažetak
Prema inovacijskoj uspješnosti (Summary Innovation Indeks (SII)) koja se temelji na 25 pokazatelja, a uključuje ljudske potencijale, uspješnost istraživačkog sustava, ulaganje privatnog i javnog sektora u istraživanje i razvoj $(R \& D)$, intelektualno vlasništvo (žigove, patente, industrijski dizajn) i ekonomske učinke (izvoz, zapošljavanje) - Hrvatska se u 2015. nalazila pri dnu EU ljestvice, odnosno inovacijska uspješnost bila je dvostruko manja od prosjeka EU-28 te 2 - 3 puta manja od inovacijskih predvodnika: Švedske, Finske, Danske, Njemačke i Nizozemske. Nasuprot trendu povećanja udjela $R \& D$ u BDP-u EU i inovacijskim politikama EU deklariranim u Lisabonskoj strategiji (2000.), zaključcima Barcelona European Council (2002.) i Horizonu 2020 koje su usmjerene na rješavanje problema tzv. „europskog paradoksa“ i nedovoljnog ulaganja, posebice privatnog sektora u $R \& D$ te na jačanje interakcije znanosti i gospodarstva po uzoru na ekonomske lidere Japan i SAD - Hrvatska bilježi višegodišnji pad ulaganja u $R \& D$, zbog čega smo s $0,76 \%$ udjela u BDP-u na razini $1 / 3$ prosjeka EU. Niska razina i višegodišnje smanjenje ulaganja u $R \& D$, slaba interakcija između $R \& D$, slaba povezanost s primarnom proizvodnjom, niska razina stranih investicija, niski apsorpcijski kapacitet i potražnja za inovacijama zbog tehnološke podinvestiranosti te višegodišnjeg smanjenja udjela $H T \mathrm{i}$ $M H T$ industrije - najveći su problemi hrvatske prerađivačke industrije, ali i prehrambene industrije kao njezine najveće grane (prema udjelu u BDVu i broju zaposlenih). Prehrambena industrija pokazala je otpornost prema recesiji te u 2015., promatrano na godišnjoj razini, bilježi stopu rasta 4\%, povećanje proizvodnosti 5 - 6\% i izvoza 19\%, a ostvarila je i značajne regionalne akvizicije, prije svega koristeći prednosti kao što su tradicija u proizvodnji hrane i pića, prepoznatljivost brandova na regionalnom tržištu i dobra sirovinska osnova. S druge strane, produktivnost je još uvijek na razini $70 \%$ prosjeka EU i najvećim dijelom posljedica je pasivnog restrukturiranja, a manjim dijelom rezultat inovacijskih aktivnosti koje, u više od $80 \%$ slučajeva, čine nabavke postrojenja, opreme i software-a. Hrvatskoj je potrebna reindustrijalizacija i razvoj prehrambene industrije
\end{abstract}


temeljen na novim tehnologijama i inovacijama te proizvodnji koja je orijentirana prema većim tržištima i izvozu, ali i prema turističkoj potražnji te boljem korištenju sirovinskog potencijala (poljoprivredne proizvodnje). Za povećanje konkurentnosti hrvatske prehrambene industrije temeljene na tehnološkim, organizacijskim i marketinškim inovacijama, uz korištenje postojećih komparativnih prednosti (tradicija, poljoprivredna proizvodnja, turistička potražnja) ključna je uloga države koja u narednom razdoblju treba znatno povećati ulaganja u $R \& D$, poreznim olakšicama i izravnim mjerama poticati razvojna istraživanja i interakciju $R \& D$, osigurati efikasniju koordinaciju $R \& D$ institucija i industrije i difuziju inovacija (npr. osnivanjem državne uprave za inovacije), poticati investiranje i poboljšati investicijsko okruženje te u suradnji s industrijom - promjenama u obrazovnom sustavu povećati apsorpcijski kapacitet za inovacije.

Ključne riječi: prehrambena industrija; konkurentnost; istraživanje i razvoj; inovacije

\section{UVOD}

Hrvatska prehrambena industrija dijeli sudbinu cjelokupnog hrvatskog gospodarstva i današnje stanje posljedica je dubokih strukturnih problema i *neoliberalnog ekonomskog modela kojeg je hrvatskom gospodarstvu, devedesetih godina prošlog stoljeća, nametnuo Međunarodni monetarni fond (MMF) kroz tzv. stand by aranžmane i kreditnim sredstvima uvjetovane restriktivne monetarne i fiskalne politike koje su uzrokovale visoku cijenu kapitala (visoke kamatne stope dodatno su povećane premijama na rizik naplate zbog ratne opasnosti i stihijske tranzicije) i pad investicija u industriji [1], a s druge strane, odustalo se od deficitarnog financiranja potražnje koja potiče gospodarske aktivnosti [2]. Naime, osiguranje proračunskih sredstava za uredno vraćanje javnog duga, odnosno kredita MMF-u značilo je štednju i smanjenje proračunskih izdataka za sektore koji utječu na kvalitetu života građana kao što su zdravstvo, školstvo te socijalno i mirovinsko osiguranje [2]. Nobelovac J.E. Stiglitz, vodeći kritičar MMF-a osudio

* Neoliberalna ekonomska doktrina javlja se u ekonomskoj teoriji u zadnjih tridesetak godina 20. stoljeća, kao odgovor i jedno od mogućih praktičnih rješenja tadašnje svjetske ekonomske stagnacije koja je nastupila nakon više od dva desetljeća ekonomskog rasta u okviru kejnzijanskog i neokejnzijanskog državnog kapitalizma. Neoliberalizam upućuje oštru kritiku kejnzijanskoj intervencionističkoj ekonomiji u kojoj je dominantna državna regulacija. Stoga neoliberalizam zagovara zaokret u kapitalističkoj ekonomiji koji bi trebao ponovno oživjeti liberalnu laissez-faire doktrinu snažnom afirmacijom tržišta kao najefikasnijeg ekonomskog sredstva alokacije resursa i regulatora ukupnih ekonomskih aktivnosti. Međutim navedeni koncept neoliberalne vizije kapitalizma pokazao je svoje slabosti, a ukoliko se zanemari početni rast, obilježavaju ga recesija, inflatorni pritisci te nezaposlenost. Ključne institucije, globalni protagonisti neoliberalnog modela su Svjetska banka (World Bank ili International Bank for Reconstruction and Development), Svjetska trgovinska organizacija (World Trade Organization) te posebice Međunarodni monetarni fond (International Monetary Fund) [2]. 
je tzv. „šok-terapije“ koje $M M F$ primjenjuje u zemljama u razvoju, a koje rezultiraju padom plaća, smanjenjem zaposlenosti, padom standarda, povećanjem siromaštva te posljedično pogoršanjem zdravlja ljudi i smanjenjem životnog vijeka [3]. Nametnuta liberalizacija i potpuno otvaranje tržišta (ukidanje administrativno-ekonomskih zapreka slobodnom kretanju roba, ukidanje kvota na uvoz, snižavanje carina i ostalih fiskalnih nameta, liberalizacija trgovinskih propisa i dr.) [2], na koje Hrvatska, posebice u ratnim i poratnim godinama kao tranzicijsko gospodarstvo i zemlja izložena agresiji, okupaciji i ratnim razaranjima, nije bila spremna, dovelo je do drastičnog povećanja uvoza, pada investicija u industriji, a posljedično i do povećanja nezaposlenosti, siromaštva i općenito - izmjene strukture hrvatskog gospodarstva $[1,4]$.

Navedeno je uz krajnje nepovoljan odnos radno-aktivnog stanovništva i umirovljenika generiralo još jedan od velikih strukturnih problema hrvatskog gospodarstva - deindustrijalizaciju koja je pogodila sve prerađivačke sektore, uključujući i prehrambenu industriju [5]. Posljedično, mijenja se i struktura hrvatskog gospodarstva u smjeru usluga (financijskog posredovanja i javne uprave), dok se udio prehrambene industrije u ukupnom BDP-u kontinuirano smanjuje. Osim neoliberalnog modela, visokih troškova tranzicije (pretvorbe i privatizacije), na proces deindustrijalizacije značajno je utjecao i rat, politička i sigurnosna nestabilnost (gubitak poslovnih veza i odvraćanje investitora) te gubitak tradicionalnih tržišta u državama u susjedstvu koje su nastale raspadom bivše države [6].

Također, problem *konkurentnosti prerađivačke industrije treba sagledavati i kroz način povećanja niske produktivnosti i sniženja troškova poslovanja koje u proteklom razdoblju nije bilo rezultat povećanja investicija te procesnih, proizvodnih, organizacijskih i marketinških inovacija, već pasivnog restrukturiranja, odnosno smanjenja radnih mjesta, koje je s druge strane produciralo nove umirovljenike i stvaralo dodatni pritisak na gospodarstvo. Posljedica je tehnološka podinvestiranost industrije i neodrživ odnos zaposlenih i umirovljenika koji danas u Hrvatskoj iznosi 1:1,18 [7].

$\mathrm{S}$ druge strane niska razina $\mathrm{i}$ višegodišnje smanjenje ulaganja $\mathrm{u} * *$ istraživanje $\mathbf{i}$ razvoj, slaba interakcija između $R \& D$, slaba povezanost s primarnom proizvodnjom,

* Konkurentnost prema definiciji OECD-a označava sposobnost zemlje da u slobodnim i ravnopravnim tržišnim uvjetima proizvede robe i usluge koje prolaze test međunarodnog tržišta, uz istovremeno zadržavanje i dugoročno povećanje realnog dohotka stanovništva [8].

** Istraživanje i razvoj (engl.: research and development (RED)) je sustavan kreativan rad u cilju povećanja znanja o prirodi, čovjeku, kulturi i društvu, i praktične primjene tog znanja. Podijeljen je na temeljno istraživanje, primijenjeno istraživanje i eksperimentalni razvoj, pri čemu ovo potonje može uključivati realizaciju tehnoloških demonstratora, tj. uređaja koji demonstriraju djelovanje novog koncepta ili nove tehnologije u odgovarajućem ili reprezentativnom okruženju. Istraživanje i razvoj ne uključuju proizvodnju $i$ kvalifikaciju predproizvodnih prototipova, alata i industrijskog inženjeringa, industrijskog dizajna ili proizvodnje. Također, ulaganja u RED su važna ne samo da bi se uvodili novi proizvodi i procesi već i da bi se uspješno adaptirali uvezeni proizvodi i tehnologije. [18] 
niska razina stranih investicija, niski apsorpcijski kapacitet i potražnja za inovacijama zbog zastarjele tehnologije te višegodišnjeg smanjenja udjela prerađivačke industrije visoke tehnologije (engl.: high-tech processing industry (HT)) i srednje visoke tehnologije (engl.: middle high-tech processing industry (MHT)) - najveći su problemi hrvatske prerađivačke industrije, ali i prehrambene industrije kao njezine najveće grane (prema udjelu u BDV-u i broju zaposlenih) $[5,9,10]$. Hrvatskoj je potrebna reindustrijalizacija i razvoj prehrambene industrije temeljen na novim tehnologijama i inovacijama i proizvodnji koja je orijentirana prema većim tržištima i izvozu, ali i prema turističkoj potražnji te boljem korištenju komparativne prednosti, odnosno poljoprivredne (sirovinske) proizvodnje.

\section{INTELEKTUALNI KAPITAL I INOVACIJE}

Kao posljedica III. znanstveno-tehnološke revolucije i IV. znanstveno-tehnološke revolucije, (tzv. industrije 4.0) koje su rezultat informacijsko-komunikacijske tehnologije (engl.: Information and Communications Technology (ICT)), biotehnologije, automatizacije, kibernetizacije i dr., klasična ekonomija koja se temeljila na radu, zemlji i kapitalu postala je ekonomija znanja (engl.: knowledge economy) u kojoj ključnu ulogu ima *intelektualni kapital, odnosno stvaralačka primjena ili sposobnost primjene znanja u proizvodnji [11,12]. U svojoj knjizi „Budućnost kapitalizma“ L.C. Thurow je napisao: „...U globaliziranom svijetu kada sve ispadne iz jednadžbe konkurentnosti,

* Pojam intelektualni kapital u ekonomskom je smislu po proi put upotrijebljen 1958. godine u financijskim analizama tržišne vrijednosti tada malih znanjem-intenzivnih poduzeća kao što je bio HewlettPackard čija se imovina sastojala uglavnom od intelektualnog kapitala, a njihova je visoka vrijednost na burzi nazivana intelektualnom premijom. Šira upotreba i popularnost termina intelektualni kapital započinje tek nakon članka Thomasa A. Stewarta: "Brainpower - How Intellectual Capital is Becoming America's Most Valuable Asset" objavljenog u časopisu Fortune 1991. godine te se ta godina smatra "rođenjem" koncepcije intelektualnog kapitala. Stewart kao "pionir intelektualnog kapitala u tome povijesnom članku, definira intelektualni kapital kao: "sumu svega što svi u kompaniji znaju, a što joj daje konkurentsku prednost na tržištu. To je intelektualni materijal - znanje, informacije, intelektualna imovina, iskustvo - koje može biti iskorišteno za stvaranje bogatstva". U svojoj prvoj knjizi, bestselleru "Intellectual Capital: The New Wealth of Organizations" iz godine 1997. Stewart je redefinirao standarde i prioritete suvremenog poslovanja, dokazujući da najvažnija imovina koju poduzeća posjeduju danas nisu materijalna dobra, oprema, financijski kapital ili tržišni udio, već su to nedodirljivi resursi: patenti, znanje radnika, informacije o kupcima i prošla iskustva koja poduzeća imaju u svojoj institucionalnoj memoriji. U knjizi „The Wealth of Knowledge: Intellectual Capital and the Twenty-first Century Organization16" iz 2001. godine Stewart prikazuje kako današnja poduzeća primjenjujući Teoriju intelektualnog kapitala u svakodnevnim operacijama, drastično povećavaju poslovni uspjeh u tržištu. Na osnovi Stewartovih postavki i brojni su drugi autori iznijeli definicije intelektualnog kapitala u kojima jasno naglašavaju razliku između znanja $i$ intelektualnog kapitala. Intelektualni kapital predstavlja znanje kao dinamičan ljudski proces, ali tek kada su znanje i inteligencija primijenjeni i transformirani u nešto vrijedno za poduzeće i potrošače njegovih proizvoda - znanje postaje vrijedna imovina, tj. intelektualni kapital poduzeća. [11] 
znanje i sposobnost organizacije ostaju jedina komparativna prednost jedne države i jedne nacionalne ekonomije. Oni koji u globaliziranom svijetu budu ekonomski vladali morat će biti spremni obrazovati, organizirati i mobilizirati intelektualnu snagu." [13]. Sposobnost stvaranja, širenja i iskorištavanja znanja i informacija postaje pokretač gospodarskog rasta, ali i općenito standarda i kvalitete života stanovništva. Proizvodni proces sve se više pretvara u znanstveni proces koji rezultira nizom revolucionarnih otkrića - novih industrijskih materijala, proizvodnih tehnologija i dizajna koji su omogućili ponudu proizvoda i usluga koji su prije nekoliko godina bili potpuno nepoznati $[14,15]$. Kao rezultat toga dolazi i do promjene kvalifikacijske strukture zaposlenih: fizički radnici zamjenjuju se tzv. umnim radnicima koji lakše prihvaćaju tuđu tehnologiju i brže razvijaju vlastitu te su spremni na stalna poboljšanja [14].

Nobelovac T.W. Shultz je rekao da je ulaganje u intelektualni kapital 3,6 puta profitabilnije od ulaganja u materijalni kapital [12.]. U najrazvijenijim zemljama svijeta više od polovice BDP-a zasniva se na intelektualnom kapitalu (Tablica 1.), dok u najjačim globalnim brandovima (npr. Apple, Google, Microsoft, IBM, Coca-Cola, McDonald's i Marlboro) intelektualni kapital čini više od 75\% ukupne tržišne vrijednosti (Slika 1.), dok je prije 30-ak godina iznosio tek 17\% [14]. U proučavanju uloge intelektualnog kapitala najdalje se otišlo u švedskoj osiguravajućoj kompaniji „Skandia“ u kojoj je 1995. razvijen model praćenja intelektualnog kapitala nazvan „Skandia Navigator“ [11]. Na Slici 2. prikazana je pozicija intelektualnog kapitala u strukturi tržišne vrijednosti tvrtke, kao nematerijalne imovine koju čini ljudski, strukturni i potrošački kapital $[11,16]$.

Tablica 1. Globalni raspored svjetskog bogatstva [14]

Table 1 Global distribution of wealth in the world [14]

\begin{tabular}{|c|l|c|c|c|c|c|}
\hline $\begin{array}{c}\text { Redni } \\
\text { broj }\end{array}$ & \multicolumn{1}{|c|}{ DRŽAVE } & $\begin{array}{c}\text { Broj } \\
\text { država }\end{array}$ & $\begin{array}{c}\text { Udio u svjetskom } \\
\text { kapitalu }\end{array}$ & $\begin{array}{c}\text { Prirodni } \\
\text { kapital }\end{array}$ & $\begin{array}{c}\text { Ljudski } \\
\text { kapital }\end{array}$ & $\begin{array}{c}\text { Proizvodni } \\
\text { kapital }\end{array}$ \\
\hline 1. & Izvoznici sirovina & 63 & $4,6 \%$ & $44 \%$ & $36 \%$ & $20 \%$ \\
\hline 2. & Manje razvijene zemlje & 100 & $15,9 \%$ & $28 \%$ & $56 \%$ & $16 \%$ \\
\hline 3. & Razvijene zemlje & 29 & $79,4 \%$ & $17 \%$ & $67 \%$ & $16 \%$ \\
\hline
\end{tabular}

Inovacija, komercijalizirano znanje, odnosno znanje pretvoreno u ekonomsku vrijednost kroz tehnologije koje su konkurentne na tržištu, postaje ključno mjerilo gospodarske konkurentnosti. Pojam inovacije odnosi se na razvoj i primjenu novog ili bitno izmijenjenog proizvoda (dobra ili usluge), postupka, nove organizacijske metode, poslovne prakse ili nove marketinške metode, te njezino uvođenje u praktičnu upotrebu odnosno - komercijalizaciju [17]. Organizacija za ekonomsku suradnju i razvoj (engl.: 
mlrd. USD

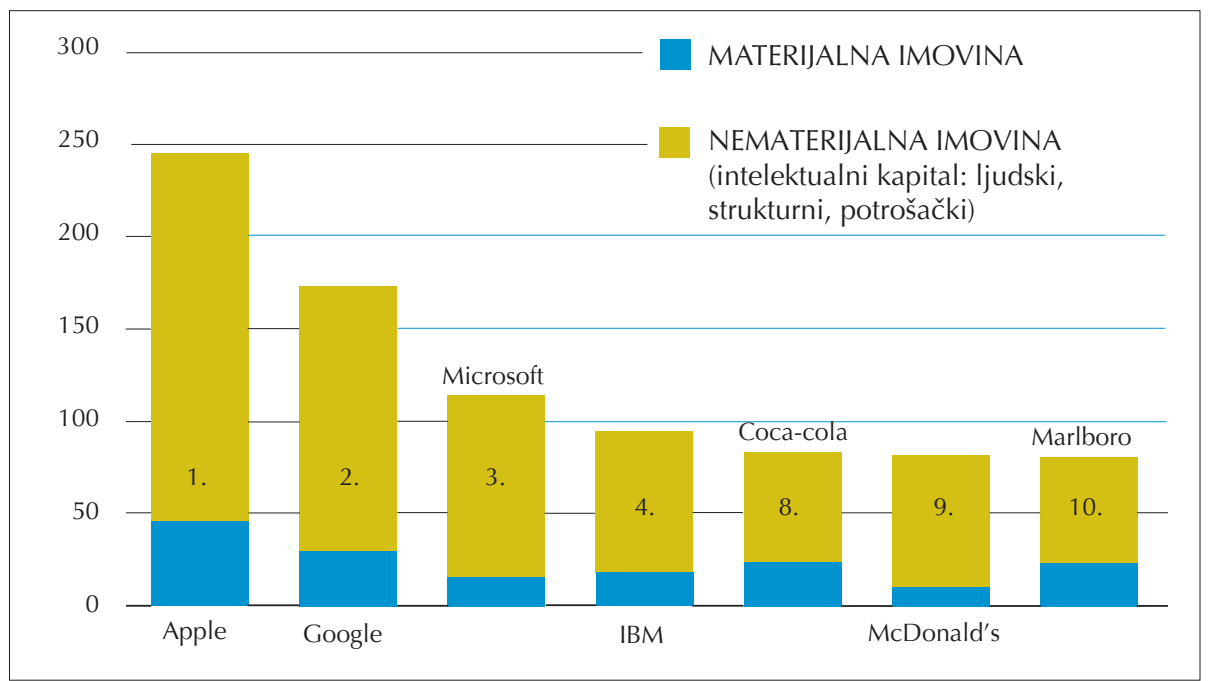

SI. 1. Udio materijalne i nematerijalne imovine u ukupnoj vrijednosti najjačih svjetskih brandova (2015.) [prilagođeno iz: 15].

Fig. 1 Percentage share of material and non-material assets in the total value of the strongest world brands (2015) [adapted from: 15].

Organisation for Economic Cooperation and Development (OECD)) u Priručniku iz Osla (III izdanje) utvrđuje 4. vrste inovacija u poduzećima: procesne i proizvodne (tehnološke) te marketinške i organizacijske (ne-tehnološke) [18]. Inovacije nisu samo revolucionarna otkrića koja su korjenito promijenila svijet (parni stroj, izmjenična struja ili nuklearna energija), inovacije nastaju svakodnevno u proizvodnim i uslužnim djelatnostima kao pokušaj tehničko-tehnološkog poboljšanja i prilagodbe pojedinih radnih operacija, a što u završnici rezultira povećanjem asortimana proizvoda i razvitkom tvrtke kroz povećanu konkurentnost (npr.: nakon istraživanja tržišta i značajnog pada prihoda u 2001. godini McDonnald `s pravi veliki zaokret prema ,zdravoj prehrani“ i uvodi nove artikle kao što su različite salate; npr. Nestle u proizvodnji Nescafe 1965. i 1967. godine uvodi granule i sušenje liofilizacijom što daje bolju topljivost kave i bolje očuvanje arome; pakiranje pića u limenkama i ambalaži različitih volumena) [19].

\section{ISTRAŽIVAČKA I INOVACIJSKA POLITIKA}

EU se krajem 1990-tih godina suočila s tzv. ,europskim paradoksom“, odnosno prema Dussauge i sur. (1992.) i Dosi i sur. (2006.) fundamentalnim paradoksom istraživanja i razvoja i spoznajom da visoka znanost i ulaganje u $R \& D$ ne proizvodi automatiz- 


\section{TRŽIŠNA VRIJEDNOST TVRTKE}

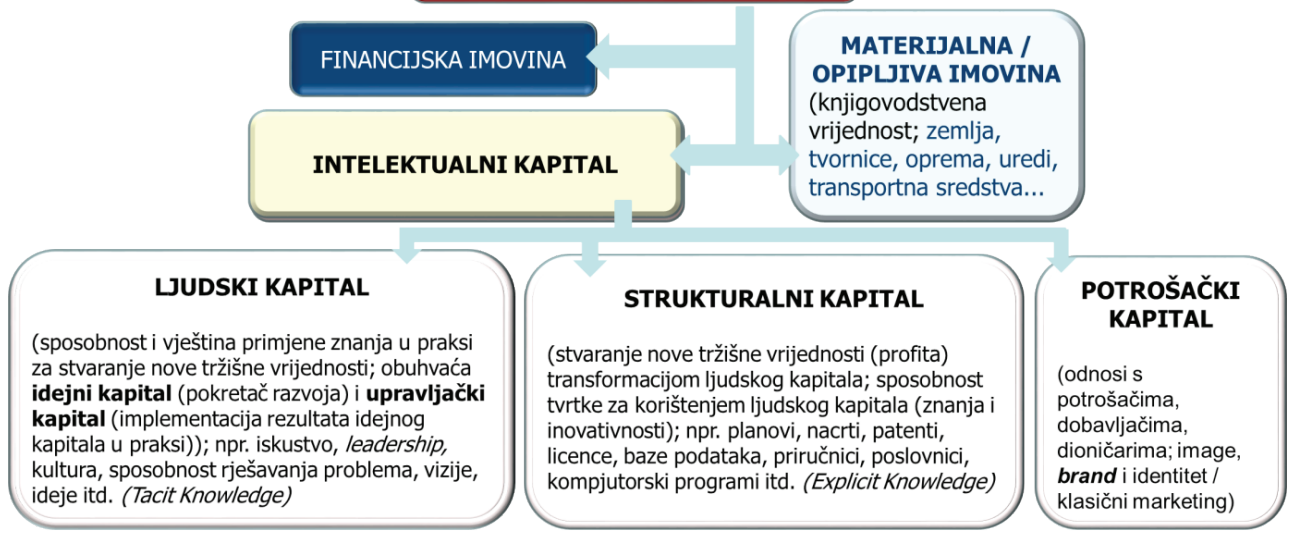

SI. 2. Shema tržišne vrijednosti kompanije prema tzv. "Skandia navigatoru“ (1995.) s modelom intelektualnog kapitala prema Stewartu (2001.) [prilagođeno iz: 11].

Fig. 2 Market value schematic of companies according to the so-called "Skandia Navigator" (1995) with the model of intellectual capital according to Stewart (2001) [adapted from: 11].

mom nove tehnologije i gospodarski rast [20], zbog čega EU zaostaje za npr. SAD-om i Japanom, dakle zemljama koje $2-3$ puta više iz BDP-a izdvajaju za znanost te u odnosu na EU imaju znatno veći udio industrije u ukupnim ulaganjima u istraživanje i razvoj $(R \& D)$. To je rezultiralo zaokretom u politici EU prema $R \& D$ i inovacijama i širem sagledavanju njihove ključne uloge u gospodarskom rastu i konkurentnosti, a što je u zadnja dva desetljeća rezultiralo nizom strateških dokumenata, programa i aktivnosti kao što je Obzor 2020 (Okvirni program EU-a za istraživanje i inovacije; engl.: Horizon 2020 - The EU Framework Programme for Research and Innovation) koji bi trebao doprinijeti ostvarivanju ciljeva ključnih strateških dokumenata Europske unije vezanih za istraživanje, tehnologijski razvoj i inovacije koji su temelj gospodarskog rasta: Europa 2020 i Unija inovacija (Innovation Union) te izgradnji Europskog istraživačkog prostora (European Research Area) [21]. Već je 2005. godine “Green paper on innovation” (GPI) identificirao ,europski paradoks“ koji se sastoji u jakim istraživačkim, ali slabim inovacijskim i ekonomskim potencijalima [22]. Definiranjem ovog problema tzv. „,inovacijskog deficita“ ukazano je na potrebu šireg sagledavanja inovacija te na potrebu institucionalne potpore ukupnom inovacijskom procesu, a ne samo $R \& D$. Ovaj dokument naglašava: potrebu intenzivnije suradnje znanosti i gospodarstava te tržišnu eksploataciju istraživanja. Kao rezultat GPI Europska komisija usvojila je "First Action Plan for Innovation" [23] koji je po prvi puta stvorio zajednički analitički i politički okvir za inovacijsku politiku u Europi unutar kojeg se inovacija poima kao rezultat kom- 
pleksne interakcije između pojedinaca, organizacija i čimbenika iz okruženja. 2000. godine Lisabonskom agendom definirao se strateški cilj prema kojem bi EU do 2010 . trebala postati najkonkurentnija i najdinamičnija ekonomija svijeta zasnovana na znanju te sposobna za održivi ekonomski rast s najvećom stopom zaposlenosti i snažnom ekonomskom i socijalnom kohezijom [24,25]. Ovaj dokument određuje kao prioritet slijedeća područja: koordinacija inovacijskih politika, regulatorni okvir povoljan za inovaciju, poticanje stvaranja i rasta inovativnih poduzeća, poboljšanje komunikacije unutar inovacijskih sustava i društvo otvoreno za inovaciju. Zaključcima iz Barcelone [26] Europsko vijeće 2002. utvrđuje da će se ulaganja u EU u istraživanja udvostručiti na $3 \%$ BDP-a, od čega $2 / 3$ iz privatnog i $1 / 3$ iz javnog sektora s posebnim naglaskom na područje $I C T$-a i biotehnologije. 2005. godine Europska komisija usvojila je novi akcijski plan: "More research and innovation: investing for Growth and Employment - a Common Approach" [27] u kojem je naglasak na veća ulaganja u istraživanje, na jačanje industrijske baze i snažniju interakciju znanosti i industrije. Okvirni programi (Šesti okvirni program - FP6 od 2002. do 2006. godine [28], Sedmi okvirni program - FP7 od 2007. do 2013. godine [29]) među glavnim su instrumentima Europske komisije za postizanje lisabonskih ciljeva, kako bi Europska unija postala "najdinamičnija i najkonkurentnija svjetska ekonomija temeljena na znanju”. U skladu s tim ciljem realiziran je i koncept Europskog istraživačkog prostora (European Research Area (ERA)), odnosno koncept slobodnog protoka znanja i tehnologija, smanjujući fragmentaciju europskog istraživanja i poboljšavajući suradnju nacionalnih programa. 2010. godine EU pokreće Uniju inovacija, inicijativu koja se sastoji od više od 30 točaka aktivnosti usmjerenih na poboljšanje uvjeta i pristupa financiranju za istraživanje i inovacije u Europi [30]. Unija inovacija u središtu je strategije Europa 2020 kako bi se osiguralo pretvaranje inovativnih ideja u proizvode i usluge kojima se potiču rast i radna mjesta. Obzor 2020. najveći je program EU-a za istraživanje i inovacije, pokrenut 2014. godine [21]. Za razdoblje od 7 godina (od 2014. do 2020.) za realizaciju programa dostupno je gotovo $80 \mathrm{mlrd}$. , od čega je većina podijeljena u tri stupa [21]:

1. izvrsna znanost (engl.: excellent science) (33\%),

2. industrijsko vodstvo (engl.: industrial leadership) u prioritetnim tehnološkim smjerovima KET (engl.: key enabling technologies): ICT, nanotehnologije, novi napredni materijali, biotehnologija, napredne proizvodne tehnologije i proizvodni procesi (24\%); radi se o ključnim tehnologijama za prijelaz iz tradicionalnog gospodarstva prema nisko ugljičnom i gospodarstvu temeljenom na znanju [9],

3. rješavanje društvenih izazova (engl.: societal challenges) (43\%) kao što su: zdravlje, demografske promjene i kvaliteta življenja; hrana, održiva poljo- 
privreda, istraživanje mora i biogospodarstvo; sigurna, čista i efikasnija energija; pametan, zelen i integriran promet; klimatske aktivnosti i učinkovito korištenje sirovina; inkluzivna, inovativna i sigurna društva.

Osim sredstava iz programa Obzor 2020., glavni izvor financiranja za ostvarivanje ciljeva strategije Europa 2020 te mjera i aktivnosti Nacionalnog programa reformi 2016. [31] čine fondovi u okviru kohezijske politike EU (ESIF - Europski strukturni i investicijski fondovi) sa cca 110 mlrd. €: 1. Kohezijski fond (CF), 2. Europski fond za regionalni razvoj (ERDF) i 3. Europski socijalni fond (ESF). Nova Kohezijska politika EU-a za programsko razdoblje 2014. - 2020. kao ,ex-ante“ uvjet zahtjeva od zemalja članica identificiranje područja specijalizacije koja najbolje odgovaraju njihovom inovacijskom potencijalu, a koja su temeljena na sredstvima i sposobnostima za korištenje sredstava EU-a u području istraživanja, tehnološkog razvoja i inovacija. Cilj je omogućiti učinkovitije korištenje ESI fondova i povećati sinergiju između sredstava EU-a i sredstava nacionalnih i regionalnih politika [18,32]. Hrvatska je 2016. usvojila Strategiju pametne specijalizacije [18] koja predstavlja strateški pristup razvoju gospodarskog sustava kroz ciljanu podršku istraživanju i razvoju. Kao i u drugim zemljama članicama EU, ova strategija treba pomoći potaknuti javne i privatne investicije u istraživanje, tehnološki razvoj i inovacije koje su usmjerene u ona tematska područja koja su kroz Strategiju pametne specijalizacije prepoznata kao područja od najvećeg potencijala za budući rast i razvoj. Radi se o pet ključnih područja: zdravlje i kvaliteta života, energija i održivi okoliš, promet i mobilnost, sigurnost te hrana i bioekonomija unutar kojih je definiran veći broj potpodručja ulaganja [18,31,33].

\section{ULAGANJE U R\&D I INOVACIJSKA USPJEŠNOST}

Inovativnost zemlje određena je kroz kvalitetu interakcije između $R \& D$, potražnje za inovacijama, apsorpcijskim kapacitetom i difuzijom znanja i inovacija putem tržišta i putem netržišne suradnje. Na Slici 3. prikazana je usporedba bruto domaćih izdataka za istraživanje i razvoj (engl.: Gross Domestic Expenditure on R\&D - GERD), odnosno udjela $R \& D$ u ukupnom BDP-u, prema Dussauge i sur. (1994.) kao najvažnijeg preduvjeta inovacija, tehnološkog razvoja i konkurentnosti [20]. Zemlje s najvećim GERDom su Japan (3,38\%), zatim SAD (2,81\%), EU-28 (2,01\%) te Kina (1,98\%), pri čemu promatrano pojedinačno, Finska (3,31\%) i Švedska (3,30\%) imaju najveći GERD u EU i u razini su s Japanom. U EU-28 te svjetskim liderima (Japan i SAD) visina GERD-a promatrana u razdoblju 2003. - 2015. sustavno raste, dok u Hrvatskoj sustavno pada i na žalost sa 0,95\% 2003. godine kada je hrvatski GERD činio cca $1 \frac{1}{2}$ GERD-a EU, 2015. godine sa 0,76\% [34] pali smo na približno 1/3 (Slika 4.) i sa Litvom, Poljskom, Rumunj- 
skom, Bugarskom, Slovačkom, Ciprom i Grčkom nalazimo se u skupini zemalja EU s najnižim GERD-om, odnosno ispod 1\%.

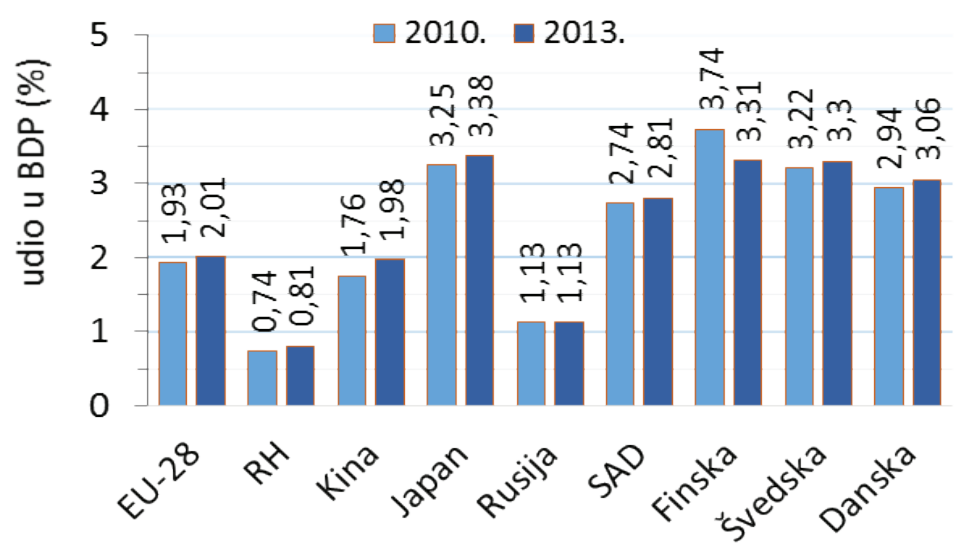

SI. 3. Usporedba udjela $R \& D$ u ukupnom BDP-u pojedinih zemalja za 2010. i 2013. [35].

Fig. 3 Comparison of the percentage share of $R \& D$ in the total GDP of individual countries for 2010 and 2013 [35].

Također, imamo i lošu strukturu GERD-a. Većina država oko polovice bruto domaćih izdataka za istraživanje i razvoj izdvaja za inženjerstvo i tehnologiju, a otprilike između petine i trećine za prirodoslovne znanosti. RH izdvaja otprilike 39\% bruto domaćih izdataka za istraživanje i razvoj na inženjerstvo i tehnologiju, slijede prirodoslovne znanosti s $21 \%$ te biomedicina i zdravlje sa 17\% [18]. Na Slici 5. prikazana je struktura izvora financiranja $R \& D$ u pojedinim državama prema kojoj su se postavljenim ciljevima Europskog vijeća (Barcelona, 2002.) [26], a u kojima je zacrtano udvostručenje ulaganja u $R \& D$ u visini 3\% BDP-a (od čega $2 / 3$ iz privatnog i $1 / 3$ iz javnog sektora), približile samo Švedska, Danska i Finska ( $>60 \%$ ), dok je EU još uvijek značajno ispod 2/3 udjela privatnog sektora, odnosno na razini cca 55\%. Samo kod svjetskih lidera, Japana i SAD-a udio privatnog sektora u ukupnim ulaganjima u $R \& D$ prelaze $70 \%$ (Slika 5.). Niska razina ulaganja u istraživanje i razvoj i javnog i privatnog sektora predstavlja jedno od najvećih ograničenja bržeg i održivijeg gospodarskog rasta u Republici Hrvatskoj [31]. Udio ulaganja u $R \& D$ hrvatskog privatnog sektora je cca $43 \%$, a glavni razlog je nedovoljna potražnja za inovacijama, odnosno niska tehnološka razina hrvatskih tvrtki koje ne mogu apsorbirati istraživačke rezultate i povećati inovativnost. 


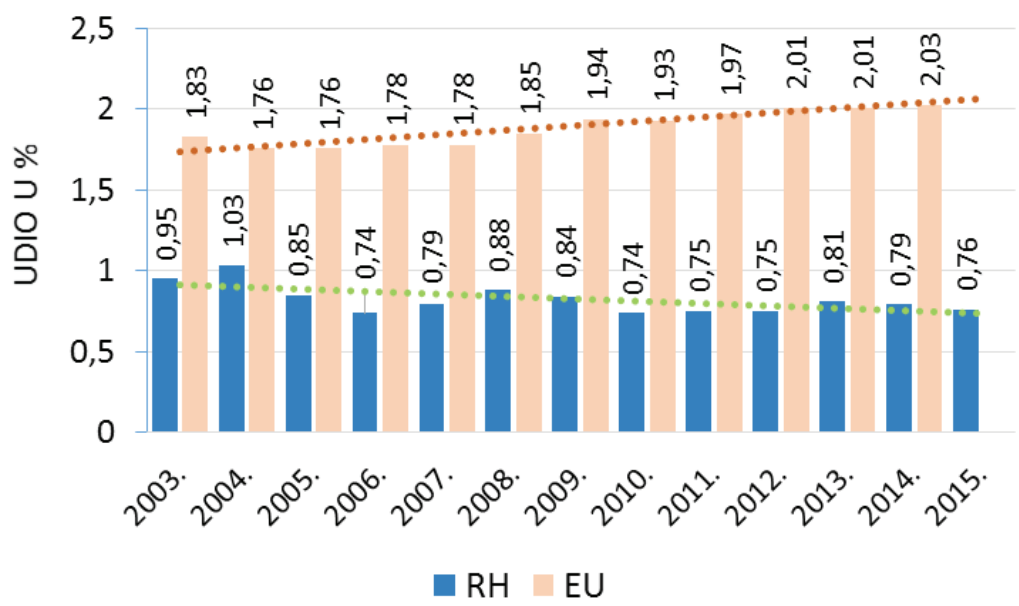

Sl. 4. Usporedba udjela $R \& D$ u ukupnom BDP-u Republike Hrvatske i EU u razdoblju 2003. 2015. [35].

Fig. 4 Comparison of the percentage share of R\&D in the total GDP for the Republic of Croatia and the EU in the period 2003 - 2015 [35].

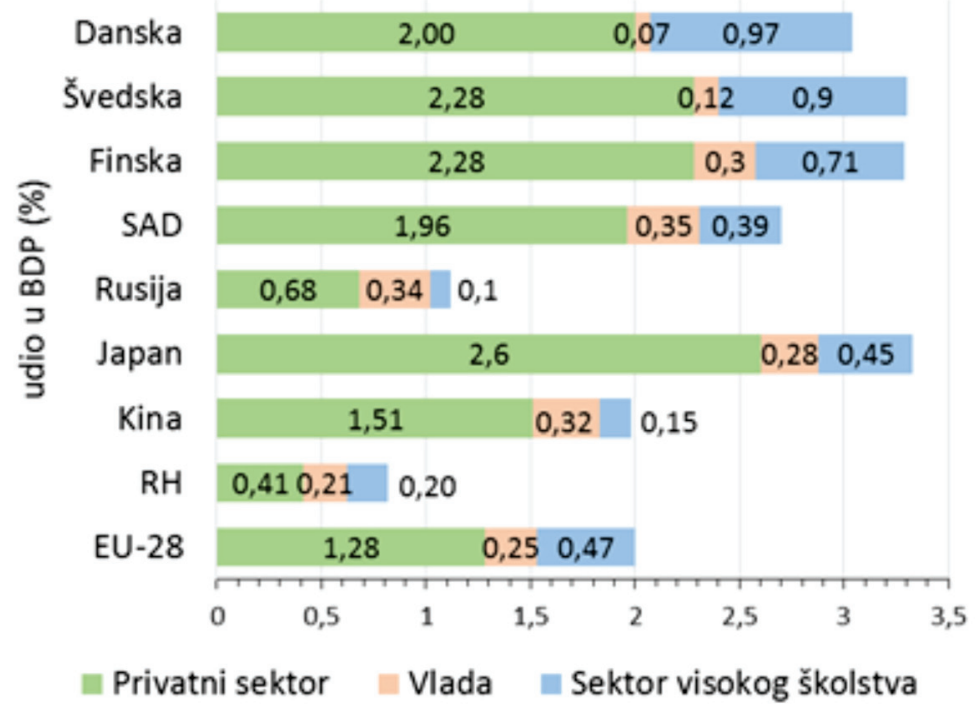

SI. 5. Izvori financiranja $R \& D$ u pojedinim državama prikazani kao udjeli $R \& D$ u BDP-u [35].

Fig. 5 Sources of $R \& D$ financing in individual states shown as percentage shares of $R \& D$ in GDP [35]. 


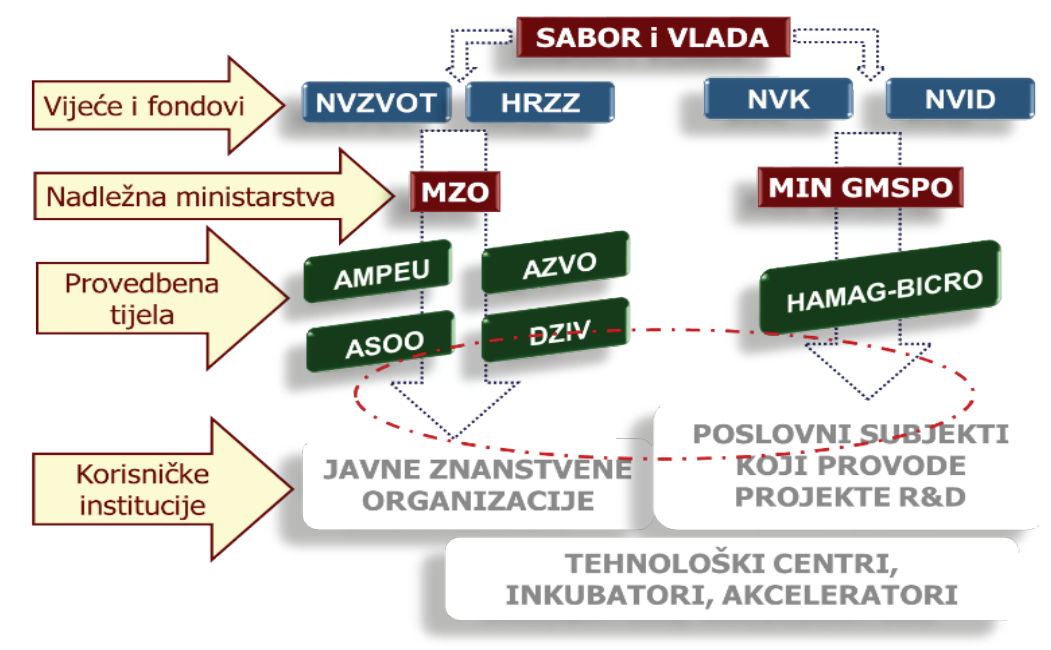

\begin{abstract}
NVZVOTR - Nacionalno vijeće za znanost, visoko obrazovanje i tehnološki razvoj; HRZZ - Hrvatska zaklada za znanost; NVK - Nacionalno vijeće za konkurentnost; NVID - Nacionalno vijeće za informacijsko društvo; ASOO Agencija za strukovno obrazovanje i obrazovanje odraslih; AZVO - Agencija za znanost i visoko obrazovanje; AMPEU - Agencija za mobilnost i programe EU; DZIV - Državni zavod za intelektualno vlasništvo; HAMAG-BICRO Hrvatska agencija za malo gospodarstvo i investicije.
\end{abstract}

SI. 6. Shema ključnih institucija u sustavu istraživanja, razvoja i inovacija RH prema MZOS-u i Izvješću OECD-a (2014.) [18].

Fig. 6 Schematic of key institutions within the research, development, and innovation system in the Republic of Croatia according to the Ministry of Science and Education and the OECD report (2014) [18].

Hrvatskoj istraživačkoj zajednici nedostaju dinamični partneri iz privatnog sektora koji su trenutno obilježeni niskim tehnološkim kapacitetima i slabim ulaganjima $\mathrm{u}$ istraživanje i razvoj. Prema podacima OECD-a iz 2012. godine, u RH se na aktivnosti istraživanja i razvoja u privatnom sektoru troši otprilike $3 \%$ državnih resursa. U usporedbi s prosjekom u zemljama OECD-a od 8,9\% i s prosjekom u državama članicama EU od 7,2\%, jasno je da je to rezultat ograničenog korištenja državnih potpora u privatnom sektoru uglavnom kroz porezne poticaje [18]. Sustav hrvatskih institucija koje su nadležne za istraživanje, razvoj i inovacije sličan je sustavima drugih europskih zemalja (Slika 6.). Međutim, osim što se istraživački prioriteti ne usklađuju s vladinim politikama gospodarskog razvitka te što u planiranju istraživačkih programa ne sudjeluju predstavnici gospodarstva, najveći je problem koordinacije provedbenih tijela međusobno te njihovog integriranog nastupa prema korisničkim institucijama na implementaciji rezultata istraživanja u praksi (na Slici 6. označeno crvenom elipsom). Taj ,institucionalni 


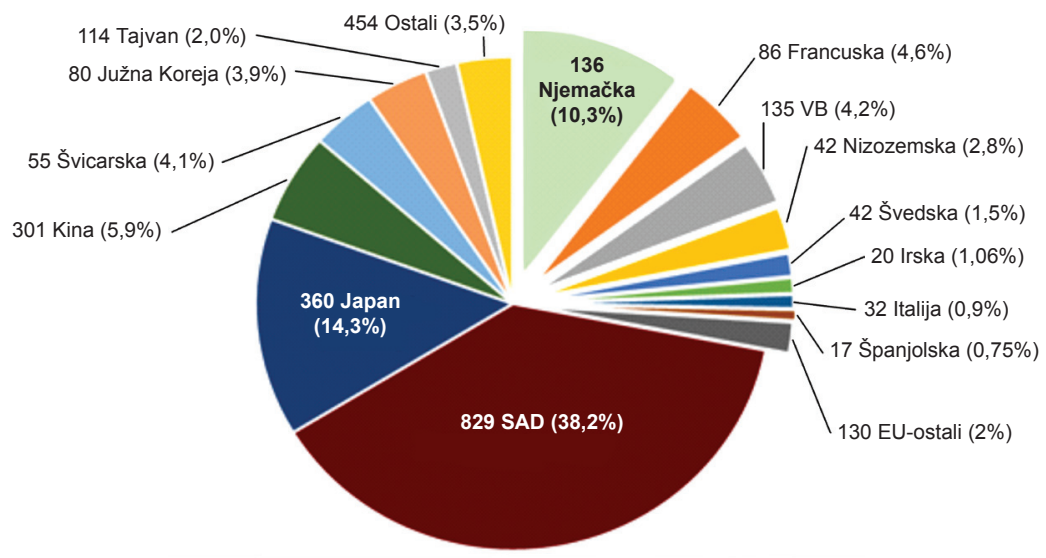

SI. 7. Raspodjela 2.500 svjetskih tvrtki - najvećih ulagača u $R \& D$. Iskazan je broj tvrtki po državama u kojima im je sjedište te je iskazan udio pojedine države u postotcima u ukupnim ulaganjima 2.500 tvrtki, a koja čine 90\% ulaganja svih svjetskih tvrtki u R\&D [36].

Fig. 7 Distribution of 2,500 companies in the world - largest investors in R\&D. Shows the number of companies according their seat location and the share of individual states in the percentage of total investments for the 2,500 companies, which accounts for $90 \%$ of R\&D investments in all the companies in the world [36].

deficit" praćen je negativnim gospodarskim okruženjem, odnosno niskim *apsorpcijskim kapacitetom i niskom potražnjom za rezultatima istraživanja i inovacijama [18].

Ako se napravi usporedba 2.500 svjetskih tvrtki s najvećim ulaganjima $\mathrm{u} R \& D$ (Slika 7.) čiji prihodi na godišnjoj razini rastu prosječno oko $2,2 \%$, a ulaganja u $R \& D$ $6,8 \%$, najveći broj tvrtki, 839 s porastom ulaganja na godišnjoj razini u $R \& D$ od $8,1 \%$ sa sjedištem je u SAD, 360 ( $\uparrow 2,65 \%)$ je japanskih, 301 ( $\uparrow 23,6 \%)$ kineskih, $136(\uparrow 6,30 \%)$ njemačkih, 135 ( $\uparrow 0,3 \%)$ britanskih, 114 tajvanskih, 86 francuskih, 80 južnokorejskih, 55 švicarskih itd., dok u EU-28 sjedište ima 603 tvrtke s porastom ulaganja u $R \& D$ na godišnjoj razini od 3,3\%.

U ukupnim ulaganjima u $R \& D$ u svijetu navedenih 2.500 tvrtki čini oko $90 \%$ ili 607,2 mlrd. $€$ pri čemu svaka tvrtka pojedinačno ulaže više od 18 mil. $€$. Ako se udio tih

* Apsorpcijski kapacitet je u osnovi sposobnost radne snage da brzo usvaja novu tehnologiju i adaptira je kako bi se poboljšala produktivnost poduzeća. Ova sposobnost ovisi o stupnju obrazovanosti radne snage te o stupnju u kojem se radna snaga redovno stručno usavršava. Potražnja za tehnologijom i inovacijama je ključna odrednica inovativnosti, jer nedostatak potražnje znači da ne postoje ekonomski poticaji da se novo znanje primjenjuje u poslovnom procesu. Ukoliko poduzeće može povećati produktivnost smanjenjem zaposlenosti, izbjegavanjem konkurencije, odnosno traženjem zaštite domaćih proizvođača ono će u pravilu pribjeći ovim lakšim metodama održanja konkurentnosti i produktionosti. S druge strane, pretjerana konkurencija može također destimulirati poduzeće na bilo kakvo inoviranje, posebice ako je tehnološki jaz u odnosu na konkurenciju prevelik. Difuzija inovacija je ključna za širenje produktionosti. Slabe veze između malih $i$ velikih poduzeća u 'lancu vrijednosti' usporavaju širenje novih tehnologija $i$ poslovnih procesa čime se smanjuje inovativnost ukupne ekonomije. 
ulaganja promatra po zemljama, tada je financijski udio SAD-a 38,20\%, EU-28 28,1\%, Japana 14,3\%, Kine 5,9\%, Švicarske 4,1\%, Južne Koreje 3,9\%, Tajvana 2\% itd. Podaci na Slici 7. potvrđuju da je podrijetlo najvećeg broja tvrtki i njihov udio u financiranju R\&D upravo u šest država - najvećih ekonomskih sila (mjereno prema visini BDP-a): 1. SAD (BDP 17,348 blrd. USD); 2. Japan (BDP 4,596 blrd. USD); 3. Njemačka (BDP 3,874 blrd. USD); 4. Kina (BDP 10,43 blrd. USD); 5. Francuska (BDP 2.833 blrd. USD); 6. Velika Britanija (VB) (BDP 2,991 blrd. USD), što potvrđuje tezu da su u današnjoj ekonomiji znanja, ekonomski rast i konkurentnost temelje prije svega na novim tehnologijama i inovacijama, a da je za to preduvjet ulaganje u $R \& D$ posebice privatnog sektora.

Tablica 2. Deset svjetskih tvrtki, najvećih ulagača u $R \& D$ u 2014. godini [36]

Table 2 Ten companies, world leaders in R\&D investments for 2014 [36]

\begin{tabular}{|c|c|c|c|c|}
\hline R.B. & TVRTKA & $\begin{array}{l}\text { DRŽAVA } \\
\text { SJEDIŠTE }\end{array}$ & INDUSTRIJSKI SEKTOR & $\begin{array}{c}R \& D \\
\text { (mil. €) }\end{array}$ \\
\hline 1. & VOLKSWAGEN & Njemačka & Automobiles \& Parts & $13.120,0$ \\
\hline 2. & SAMSUNG & Južna Koreja & Electronic \& Electrical Equipment & $12.187,0$ \\
\hline 3. & MICROSOFT & SAD & Software \& Computer Services & $9.921,7$ \\
\hline 4. & INTEL & SAD & Technology Hardware \& Equipment & $9.502,5$ \\
\hline 5. & NOVARTIS & Švicarska & Pharmaceuticals \& Biotechnology & $8.217,6$ \\
\hline 6. & GOOGLE & SAD & Software \& Computer Services & $8.098,2$ \\
\hline 7. & ROCHE & Švicarska & Pharmaceuticals \& Biotechnology & $7.422,1$ \\
\hline 8. & $\begin{array}{l}\text { JOHNSON \& } \\
\text { JOHNSON }\end{array}$ & SAD & Pharmaceuticals \& Biotechnology & $6.996,1$ \\
\hline 9. & TOYOTA & Japan & Automobiles \& Parts & $6.858,4$ \\
\hline 10. & PFIZER & SAD & Pharmaceuticals \& Biotechnology & $6.844,6$ \\
\hline
\end{tabular}

Na žalost među tvrtkama liderima, dakle njih 2.500 nema niti jedna tvrtka iz RH, odnosno niti jedna tvrtka u Hrvatskoj pojedinačno ne ulaže u $R \& D$ više od 18 mil. $€$. Od 2.500 tvrtki 59 tvrtki je iz područja prehrambene industrije s godišnjim ulaganjima u $R \& D$ od 8,6 mlrd. $€$ ili 1,4\% od ukupnih ulaganja svih 2.500 tvrtki. Iz područja prehrambene industrije 16 tvrtki je sa sjedištem u EU koja je najveći proizvođač i izvoznik hrane u svijetu. Tih 16 tvrtki ima i najveći udio u financiranju $R \& D$-a u usporedbi sa ostalim zemljama u kojima je sjedište ostalih prehrambenih tvrtki (Slika 8.). [36] U Tablici 2. dan je prikaz 10 globalnih tvrtki s najvećim ulaganjima u R\&D u 2014. godini pri čemu prve četiri tvrtke ulažu godišnje u $R \& D$ u visini hrvatskog BDP-a. Najzastupljenije su industrije iz područja HT i MHT, odnosno automobilska industrija, elektronička, ICT, ali i sektor farmaceutske industrije i biotehnologije. 


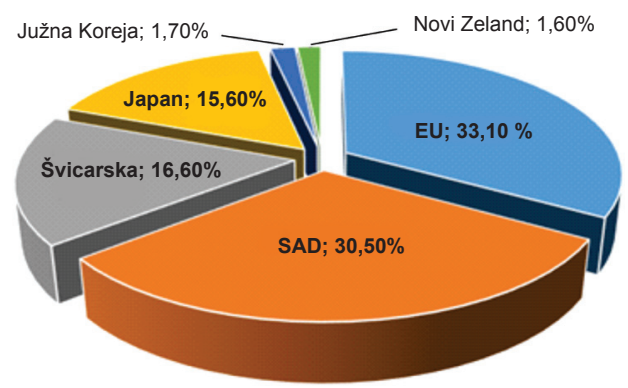

Sl. 8. Udio ulaganja pojedinih zemalja u $R \& D$ putem 59 tvrtki - najvećih ulagača u $R \& D$ prehrambene industrije [36].

Fig. 8 Percentage share of $R \& D$ investments individual countries have made through 59 companies - largest investors in food industry $R \& D$ [36].

Inovacijska uspješnost je kompleksan parametar koji obuhvaća 25 pokazatelja podijeljenih u 3 skupine: 1. osnovni čimbenici koji omogućuju inovacije (npr. ljudski resursi kao što su novi doktori znanosti u dobi 25 - 34 godine, \% stanovništva s tercijarnom edukacijom u dobi 30 - 34 godine, \% mladih u dobi 20 - 24 sa srednjom školom, zatim otvoreni, izvrsni i privlačni istraživački sustavi kao što su publikacije u Web of Science, ne-EU doktoranti i dr. te GERB); 2. aktivnosti poduzeća (npr. investiranje u R\&D, povezivanje i poduzetništvo te intelektualno vlasništvo kao što su patenti, žigovi i industrijski dizajn); 3. rezultati (npr. inovatori kao što su poduzetnici koji su implementirali inovacije i povećali broj zaposlenih te ekonomski učinci na zapošljavanje, izvoz i trgovinu inovativnih proizvoda i dr.). Prema inovacijskoj uspješnosti u 2014. godini, odnosno SII (engl.: Summary Innovation Indeks) Hrvatska se nalazi pri samom dnu EU-ljestvice ispred Rumunjske i Bugarske, na granici između umjerenih inovatora i skromnih inovatora te sa indeksom 0,28 gotovo je dvostruko slabija od prosjeka EU-28 i 3 puta od Južne Koreje $(0,726)$, SAD $(0,703)$ i Japana (0,701) (Slika 9.) [37]. Prema svih 25 pokazatelja Hrvatska je značajno ispod prosjeka EU, posebice u području *intelektualnog vlasništva i $R \& D$ (tehnološka

* Intelektualno vlasništvo obuhvaća sve što je stvorio ljudski um. Uobičajene vrste prava intelektualnog vlasništva uključuje patente, žigove, industrijske dizajne i autorska prava. Žigovi su uobičajeno odraz kvalitete i produktionosti u sektoru uslužnih djelatnosti, jer se oni registriraju na temelju marketinških aktionosti. Prvenstvena svrha zaštite žigom je zaštita i očuvanje ugleda proizvoda ili usluga, odnosno samog proizvođača ili pružatelja usluge, na tržištu. Temeljna funkcija žiga je razlikovanje proizvoda i usluga poduzetnika na tržištu. Žigom se naime štiti razlikovni (distinktioni) znak kojim se označava određeni proizvod ili usluga - ime, logotip, amblem, etiketa ili neki drugi znak koji je razlikovan u odnosu na proizvode i usluge koje se tim znakom obilježava. Na taj način osigurava se međusobno razlikovanje proizvoda i usluga poduzetnika na tržištu, odnosno omogućuje se potrošaču da identificira proizvod ili uslugu koji odgovaraju njegovim potrebama ili očekivanjima, odnosno izvor takvog proizvoda ili usluge. Od svih oblika intelektualnog vlasništva uz tehnološke inovacije najčešće se veže patent, budući da se patentom štiti bit tehnoloških inovacija - izum. Patent je pravo priznato za izum koji nudi novo rješenje nekog tehničkog problema, što se može odnositi na proizvod, postupak ili novu primjenu postojećeg proizvoda ili postupka. Izumi podrazumijevaju stvaranje novih ideja ili znanja u cilju rješavanja određenog tehničkog problema i za razliku od patenta ne moraju nužno biti povezani s komercijalizacijom. Stvaranje tehnološke inovacije. Industrijskim dizajnom kao jednim od oblika intelektualnog vlasništva štite se prostorna ili plošna obilježja proizvoda, vidljiva pri njegovoj normalnoj (namjenskoj) uporabi. kontekstu zaštite intelektualnog vlasništva industrijskim dizajnom smatra se isključivo izgled proizvoda. Dizajn je ono što proizvod čini privlačnim, dopadljivim ili poželjnim, te na taj način bitno pridonosi prodaji proizvoda i povećanju njegove komercijalne vrijednosti. [39]. 


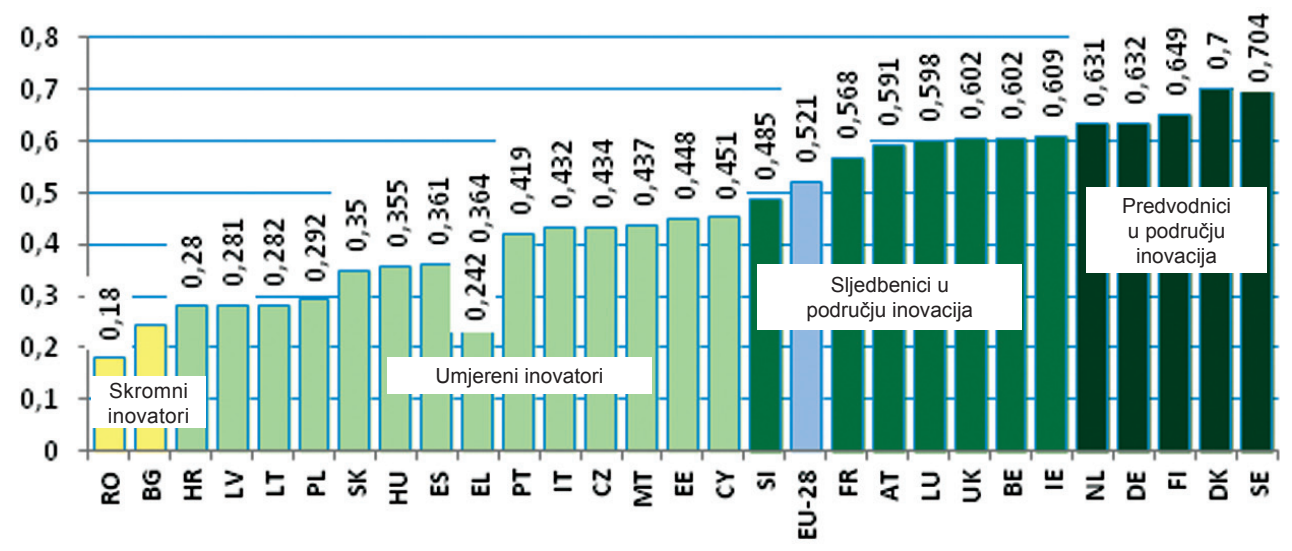

SI. 9. Uspješnost EU država u području inovacija, odnosno SII (Summary Innovation Indeks) za 2015. godinu [37].

Fig. 9 Success of EU Member States in the area of innovation, i.e. SII (Summary Innovation Index) for 2015 [37].

inovativnost i snaga intelektualnog kapitala), osim pokazatelja da je više od $95 \%$ stanovništva u dobi od 20 do 24 godine završilo neku vrstu više srednje škole, dok je 2011. godine taj prosjek u zemljama EU 27 iznosio 79,5\%. U svijetu je u 2015. godini odobreno 68.403 patenata od čega 3.348 ili 4,89\% spada u područje kemije hrane i biotehnologije (Food Chemistry \& Biotechnology), a zemlje s najvećim brojem patenata su SAD, Njemačka i Japan (Slika 10.) [38]. U EU je u 2015. godini odobreno 31.022 patenta od čega gotovo polovica 14.122 ili 45,5\% u Njemačkoj, 5.433 u Francuskoj, 2.476 u Italiji, 2.097 u Velikoj Britaniji, 1.969 u Švedskoj itd., a njihov broj na godišnjoj razini raste po stopi od 10\%.

Zabrinjavajući je podatak da se Hrvatska prema intelektualnom vlasništvu, odnosno registriranim patentima te odobrenim žigovima $\mathrm{i}$ industrijskom dizajnu nalazi na začelju EU-28, posebice zbog činjenice da korištenje prava intelektualnog vlasništva u EU-28 generira izravno i neizravno 1/3 radnih mjesta. Sa 31 žigom na 1 milijun stanovnika u odnosu na 126 u EU Hrvatska se nalazi na posljednjem mjestu, sa 4,3 industrijska dizajna na milijun stanovnika u odnosu na 106,8 u EU Hrvatska je na pretposljednjem 27. mjestu, dok je sa 6,6 patenata na milijun stanovnika u odnosu na 111,6 patenata $u$ EU na 26. mjestu. [38] Da je Hrvatska na začelju EU prema korištenju intelektualnog vlasništava i najvažnijim pokazateljima konkurentnosti industrije dokazuje i podatak o poziciji Hrvatske na ljestvici globalne konkurentnosti gdje je prema globalnom indeksu konkurentnosti za razdoblje 2016./2017. Hrvatska 74. od 138 zemalja, dok smo prema jednom od najvažnijih pokazatelja konkurentnosti - inovativnosti tek na 103. mjestu [40]. Dodatni problem je status poduzetništva u hrvatskom društvu i opći nedostatak poduzetničkih vještina. 
Sl. 10. Odobreni patenti u svijetu u 2015. godini [38].

Fig. 10 Approved patents in the world in 2015 [38].

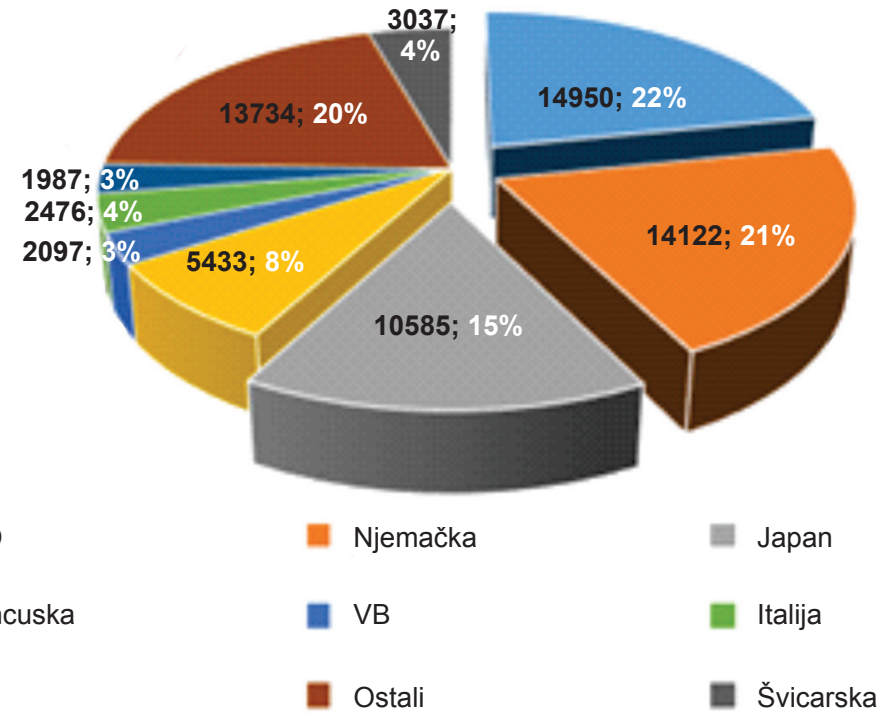

Postotak zaposlenika u dobi od 18 do 24 godine uključenih u obrazovanje i izobrazbu iznosi samo 5,9\% (2011.), dok je prosjek na razini EU-27 35,8\%. Samo 2,3\% ukupnog broja zaposlenih osoba sudjeluje u trajnim procesima osposobljavanja i učenja (prosjek na razini EU-27 je 8,9\%). Također, u ovom trenutku većinu patenata na državnoj razini registrirale su fizičke osobe (88\%), dok je trend u EU obrnut, većinu novih patenata registrira poslovni sektor. [34] Prema podacima Državnog zavoda za intelektualno vlasništvo [41] u 2015. godini odobreno je 5 patenata, 2 industrijska dizajna i 368 žigova u području prehrambene industrije (hrvatski nositelji prava).

\section{OSNOVNI EKONOMSKI POKAZATELJI I INOVATIVNOST HRVATSKE PREHRAMBENE INDUSTRIJE}

Prehrambena industrija (proizvodnja hrane i pića) jedan je od najznačajnijih industrijskih sektora u Hrvatskoj s najvećim udjelom u prerađivačkoj industriji $(28,2 \%$ u 2015.) te najvećim udjelom zaposlenih (19,2\% u 2015.; proizvodnja hrane 17,1\%, a pića 2,1\%) (Tablica 3.) [10,42]. Osim učinaka na proizvodnju i zaposlenost ima veliki značaj za razvoj poljoprivredne proizvodnje $[42,43]$. Hrvatska prerađivačka industrija čini 16,02\% ukupnog BDV-a, dok je prehrambena industrija kao i u EU njezin najsnažniji sektor prema prometu, dodanoj vrijednosti, broju zaposlenih i broju tvrtki, pri čemu proizvodnja hrane i pića čini 4,1\% ukupnog BDV-a (proizvodnja hrane 3,2\%, a proizvodnja pića 0,9\%) (Tablica 3.). Najveći problem predstavlja negativna vanjskotrgovinska bilanca hrane i pića, odnosno vanjskotrgovinski deficit koji iznosi cca 900 mlrd. $€$ te pokrivenost uvoza izvozom od tek 56\%. S druge strane, EU je najveći proi- 
zvođač i izvoznik hrane u svijetu sa suficitom vanjskotrgovinske bilance od 27,6 bil. € i pokrivenošću uvoza izvozom od 143,05\% koji na međugodišnjoj razini raste po stopi od 10\% [44]. Prema udjelu u prerađivačkoj industriji (4,1\%) Hrvatskoj je sektor proizvodnje hrane i pića ekonomski značajniji nego EU (1,8\%) prema utjecaju na BDV, zbog čega je negativna vanjskotrgovinska bilanca još problematičnija [42]. Povećanje izvozne konkurentnosti prehrambene industrije preduvjet je njezina rasta. Od analiziranih tržišta hrvatski prehrambeni sektor najveću jediničnu cijenu ostvaruje na tržištu EU-15, ali je sve veća prisutnost i na tržištima u razvoju (Rusija) i brzo rastućim tržištima (Turska). Najviše prehrambenih proizvoda uvozimo iz Njemačke, Italije, Mađarske, Nizozemske (meso, voće i povrće, mliječni proizvodi) pri čemu treba istaknuti problem sve većeg

Tablica 3. Usporedba ekonomskih pokazatelja proizvodnje hrane i pića Republike Hrvatske i Europske unije [prilagođeno iz: 9,10,44]

Table 3 Comparison between the economic indicators for food and beverage production in the Republic of Croatia and the European Union [adapted from: 9,10,44]

\begin{tabular}{|c|c|c|}
\hline POKAZATELJI & $\mathrm{RH}$ & EU \\
\hline doprinos (udio) proizvodnje hrane i pića BDV-u & $4,1 \%$ & $1,8 \%$ \\
\hline udio proizvodnje hrane i pića u prerađivačkoj industriji & $28,2 \%$ & $12,8 \%$ \\
\hline broj zaposlenih u prerađivačkoj industriji & cca 200.000 & 4,2 mil. \\
\hline $\begin{array}{l}\text { Udio zaposlenih u proizvodnji hrane i pića u ukupnom } \\
\text { broju zaposlenih u prerađivačkoj industriji }\end{array}$ & $\begin{array}{c}19,2 \% \\
(\text { cca } 38.000)\end{array}$ & $15 \%$ \\
\hline izvoz $(€)$ & 1,088 mlrd. & 91,7 bil. \\
\hline uvoz $(€)$ & 1,956 mlrd. & 64,1 bil. \\
\hline vanjskotrgovinska bilanca $(€)$ & $-0,868 \mathrm{mlrd}$ & $+27,6$ bil. \\
\hline pokrivenost uvoza izvozom & $55,6 \%$ & $\begin{array}{c}143,05 \% \\
\text { porast }>10 \%\end{array}$ \\
\hline $\begin{array}{l}\text { doprinos SMEs (do } 250 \text { zaposlenih) ukupnom prometu } \\
\text { i dodanoj vrijednosti proizvodnje hrane i pića }\end{array}$ & $54,6 \%$ & $\begin{array}{l}\text { oko } 50 \% \\
550 \text { bil. } €\end{array}$ \\
\hline $\begin{array}{l}\text { najsnažniji sektori prema prometu, } \\
\text { dodanoj vrijednosti, zaposlenima i broju } \\
\text { kompanija }\end{array}$ & \multicolumn{2}{|c|}{$\begin{array}{l}\text { 1. Mesna industrija } \\
\text { 2. Industrija pića } \\
\text { 3. Mliječna industrija }\end{array}$} \\
\hline
\end{tabular}

uvoza žive stoke i mesa te mlijeka što ukazuje na kronični problem pada farmske proizvodnje. Rezultati input-output analize pokazuju da izvoz prehrambene industrije ima najveće multiplikativne učinke na poljoprivrednu proizvodnju i trgovinu, te u nešto manjoj mjeri na kopneni prijevoz, opskrbu električnom energijom, te poslovne usluge. U odnosu na druge industrijske sektore prehrambena industrija ima treći najveći multiplikativni učinak na output koji ostvaruje hrvatska ekonomija, što dodatno potvrđuje strateški karakter ovog sektora i potrebu revizije postojećeg nacrta Industrijske strate- 
gije RH 2014. - 2020. prema kojoj je prehrambena industrija, osim prerade voća i povrća i ostalih prehrambenih proizvoda, svrstana među *,.̌uvare“ (industrije koje su dosegle svoje granice rasta i nemaju potencijal za daljnji rast), a ne „pokretače“ industrijske proizvodnje. $[9,42,43]$.

Proizvodnja hrane i pića bilježi pozitivne međugodišnje stope rasta (u 2015. 4,1\% proizvodnja hrane i 3,8 \% proizvodnja pića), rast proizvodnosti (u 2015. 4,1\% proizvodnja hrane i 6,4 \% proizvodnja pića), rast izvoza hrane 2014./2015. za 16,3\%, dok je uvoz povećan za 9,1\%, rast izvoza pića 2014./2015. za 13,4\%, a uvoza od 10,0\% [10] što uz činjenicu da u prehrambenoj industriji imamo snažnu tradiciju, dobru sirovinsku osnovu i veliki potencijal u turističkoj potražnji govori o velikom razvojnom potencijalu ovog sektora. Međutim, produktivnost prehrambene industrije je još uvijek na razini

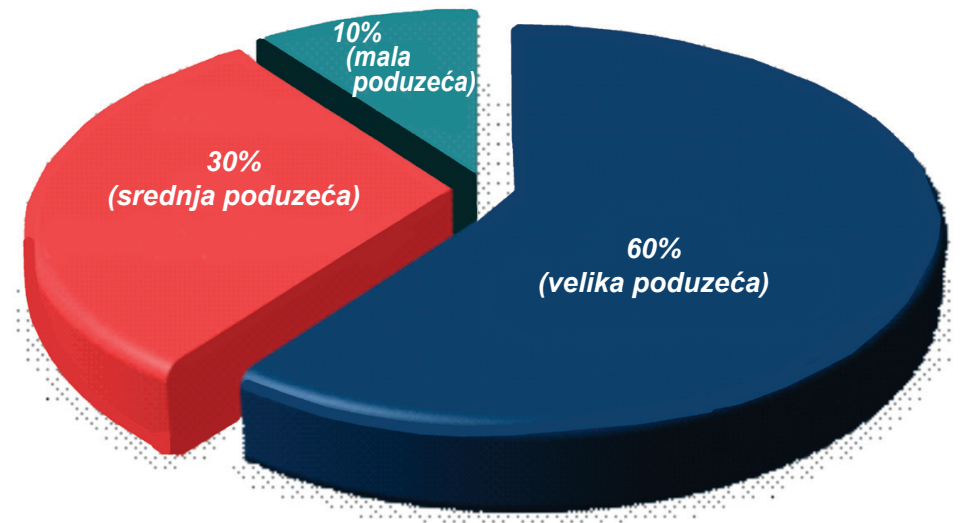

SI. 11. Podjela hrvatskih poduzeća prema veličini i udjelu investiranja u R\&D [34].

Fig. 11 Distribution of Croatian companies according to their size and the percentage share of investments in $R \& D$ [34].

$70 \%$ prosjeka EU i kao i u cijelom prerađivačkom sektoru najvećim dijelom posljedica je pasivnog restrukturiranja, a manjim dijelom rezultat tehnološkog razvoja i inovacijskih aktivnosti koje, u više od $80 \%$ slučajeva, čine nabavke postrojenja, opreme $\mathrm{i}$ software-a.

* U skladu s modelom vrednovanja i rangiranja poddjelatnosti, sve poddjelatnosti su podijeljene u pet osnovnih skupina i rangirane u skupinama kojima pripadaju. Skupine u koje su razvrstane industrijske poddjelatnosti su: 1. "Pokretači“ - velike izvozno orijentirane poddjelatnosti koje ostvaruju pozitivan EBITDA i zapošljavaju značajan broj zaposlenih. Od ovih poddjelatnosti očekuje se da ostvaruju veće stope rasta i zapošljavanja od kretanja BDP-a, odnosno preko 5\%, koji se temelji prvenstveno na povećanju izvoza. Ključne industrijske poddjelatnosti. 2. "Čuvari" - velike industrijske poddjelatnosti usmjerene na domaće tržište koje ostvaruju pozitivan EBITDA i zapošljavaju značajan broj zaposlenih. S obzirom na orijentaciju na domaće tržište, očekuju se stope rasta u skladu s kretanjima nacionalne ekonomije, u prosjeku od 1 do 5\% (zadržavanje ili blago povećanje broja zaposlenih). [9] 
Hrvatska srednja i velika poduzeća ulažu više od $90 \%$ od ukupnih privatnih investicija u $R \& D$, dok velika poduzeća ulažu najveći udio (npr. Agrokor Grupa, Podravka, Atlantic Grupa, Heineken), i to u području poljoprivrede te proizvodnje ulja, sladoleda, smrznute hrane, flaširane vode, bezalkoholnih pića, vina i mesnih prerađevina, s više od $60 \%$ investicija u $R \& D$ (Slika 11.). Mikro i mala poduzeća sudjeluju s tek $8 \%$ [34].

\section{INOVACIJSKI TRENDOVI U PROIZVODNJI HRANE I PIĆA}

Trendovi u proizvodnji hrane i pića (upravljanje kvalitetom i sigurnosti hrane, osiguranje zdravije hrane i ekološki održiva proizvodnja hrane) te preferencije potrošača najsnažniji su pokretači inovacija. Na zahtjeve potrošača danas značajno utječe ubrzani način života, nedostatak vremena za pripremu hrane, povećanje životne dobi, veća svijest o zdravijoj hrani i opasnostima vezanima uz hranu, povećani udio samačkih domaćinstava (promjene u pakiranju i veći udio grickalica i gotove hrane i pića), osjetljivost na cijenu uslijed velike konkurencije sličnih ili zamjenskih proizvoda, povećana društvena odgovornost i aktivizam (ekološki i etički standardi) i sl. Današnji kupci postavljaju zahtjeve za hranom i pićem sljedećih svojstava: vrhunski okus i zadovoljstvo, manje soli i masnoća, više biljne hrane i vlakana, poboljšanje pakiranja, personalizirana hrana (gotova ili polugotova jela), funkcionalna hrana, hrana prilagođena životnom stilu u svakoj životnoj dobi, prevencija bolesti povezana sa životnom dobi, ekološka i tradicionalna hrana, hrana s minimalnim promjenama prirodnih i nutritivnih svojstava, odgovorno deklariranje, hrana proizvedena u skladu s etičkim i ekološkim standardima (dobrobit životinja, manja potrošnja energije i sl.). U European Technology Platform (ETP) on Food for Life (Strategic Research Agenda 2007-2020) naglašava se uloga prehrane u poboljšanju javnoga zdravstva te značaju edukacije i podizanja svijesti potrošača o zdravoj prehrani [46]. Na Slici 12. prikazana su očekivanja potrošača podijeljena u pet vektora strukturiranih prema inovacijskim trendovima koja pokazuju da je više od 57\% očekivanja usmjereno prema inovacijama koje su opisane vektorom „zadovoljstvo“, odnosno koje su usmjerene na profinjenost, povećanje palete senzorskih svojstava, egzotičnost i zabavu $[44,45]$. Očekivanja potrošača u području inovacija za povećanje zdrav-stvenih svojstava hrane kao što su smanjenje udjela masnoća, šećera i soli, zatim povećanje vlakana, vitamina, minerala, probiotičko djelovanje hrane, hrana s očuvanim prirodnim svojstvima te biljnog podrijetla - znatno su manja od vektora „zadovoljstva“ i čine 17,8\% (Slika 12.). Na trećem mjestu sa 17,6\% su očekivanja oko povoljnosti kao što su personalizirana hrana, gotova jela, povoljnost pri kupnji i plaćanju, dostupnost, samo-doziranje, samo-brtvljenje, samo-zagrijavanje, jednostavno rukovanje, veća trajnost i jednostavno zatvaranje. Zanimljivo je da je tek na 4. mjestu fizičko djelovanje hrane, odnosno kozmetičko djelovanje, djelovanje na vitkost i ener- 
getska svojstva sa $6,10 \%$. Također, gotovo zabrinjavajuće zvuči podatak o ekološkoj osviještenosti, odnosno činjenici da je etičnost u proizvodnji hrane i pića na zadnjem mjestu očekivanja potrošača (Slika 12.) [44].

Naime, sa 1,40\% vektor „etičnosti“" koji obuhvaća sprječavanje zagađivanja okoliša, dobrobit životinja, primjenu ambalažnog materijala s mogućnošću reciklaže, korištenje manje energije pri proizvodnji i pripremi obroka - na zadnjem je mjestu prema očekivanjima potrošača što dodatno potvrđuje da smjer inovativnosti u proizvodnji hrane i pića treba usmjeriti prije svega prema proizvodima koji su zabavni, egzotični i sofisticirani te zdraviju hranu. Na Slici 13. prikazano je 11 najinovativnijih sektora prehrambene industrije u razdoblju 2014./2015. u EU. Najveći udio u inovacijama ima sektor proizvodnje sokova, mliječnih proizvoda, delikatesnih smrznutih proizvoda i gotovih jela. [44]

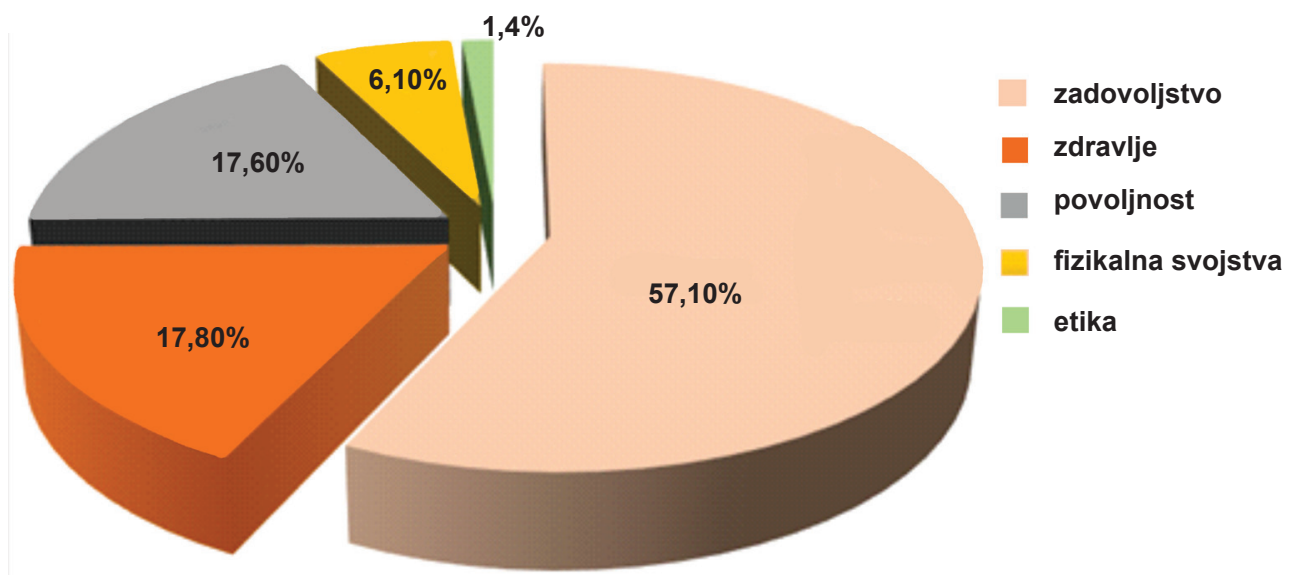

SI. 12. Očekivanja potrošača podijeljena u 5 vektora strukturiranih prema inovacijskim trendovima u proizvodnji hrane i pića [44].

Fig. 12 Consumer expectations divided into 5 vectors, which are structured according to innovation trends in the production of food and beverages [44].

Inovacije u prehrambenoj industriji uglavnom su ,,inkrementalne“ ili imitacije dok samo 3\% predstavljaju potpuno nove proizvode kao što su svojevremeno bili hrvatski brandovi: vegeta ili cedevita. Također, oko 30\% inovacija u prehrambenoj industriji u području su ambalaže (novi ambalažni materijali, materijali s mogućnošću reciklaže, biorazgradivi materijali, aktivno i inteligentno pakiranje u svrhu praćenja svježine te povećanja trajnosti i kvalitete hrane, personalizirano pakiranje, ambalaža koja se može tretirati u mikrovalnoj pećnici, ambalaža sa samodoziranjem, samobrtvljenjem, samozagrijavanjem, ambalaža koja osigurava jednostavno rukovanje i jednostavno zatvaranje i sl.). Digitalizacija je glavni pokretač inovacija u području distribucije hrane i pića koja osigurava izravnu komunikaciju s potrošačima (on-line prodaja; e-marketing), a posebno otvara velike mogućnosti informiranja potrošača. [45] 
Izazovi na koje će prehrambena industrija trebati odgovoriti u narednom razdoblju su:

a) Osigurati izbor zdrave hrane kao jednostavan izbor pod najpovoljnijim uvjetima,

b) Isporuka zdrave hrane,

c) Razvoj prehrambenih proizvoda s dodanom vrijednosti koji su superiorni kvalitetom, pogodnostima, dostupnosti i pristupačnosti,

d) Osigurati sigurnu hranu i povjerenje kupaca,

e) Doprinijeti održivoj proizvodnji hrane,

f) Kontrola lanca proizvodnje hrane,

g) Tehnološki transfer, konkurencija i interakcija s potrošačima.

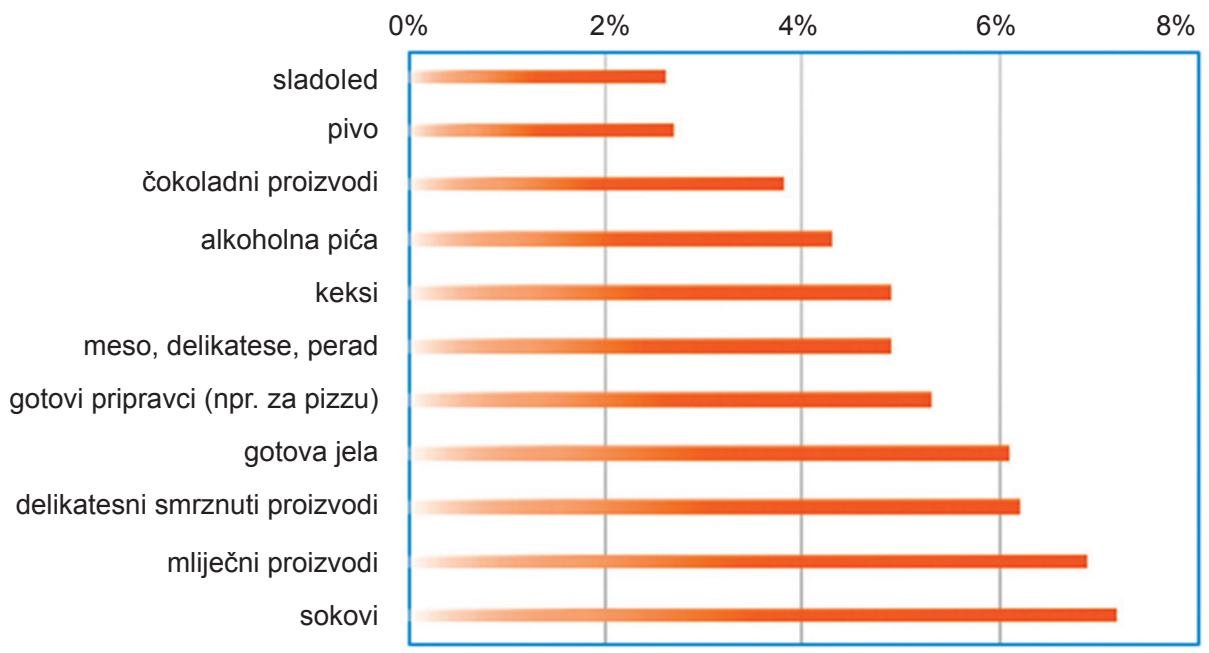

SI. 13. 11 najinovativnijih sektora prehrambene industrije u razdoblju 2014./ 2015. u EU (\%-tni udio u ukupnim inovacijama u području proizvodnje hrane i pića) [44].

Fig. 13 Eleven most innovative food industry sectors in the period 2014/2015, in the EU (percentage share in the total amount of innovation in the area of food and beverage production) [44].

Za očekivati je da će se inovacije najviše jačati u području automatizacije proizvodnje i poboljšanja tehnologija za provođenje nadzora kvalitete u proizvodnom lancu s izravnim utjecajem na povećanje produktivnosti te kvalitete i sigurnosti proizvoda. Zatim u području dodataka i aroma te novih procesnih tehnika i metoda konzerviranja s minimalnom degradacijom prirodnih svojstava hrane. Također, sve više će rasti potražnja za tzv. personaliziranim proizvodima što će značiti kraći životni ciklus proizvoda, jer će proizvodi biti više diferencirani i češće će se mijenjati. ETP definira tri inovativna područja koja će u budućnosti zahtijevati multidisciplinarni pristup: a) u nastajanju (znanost o potrošačima, održiva proizvodnja); b) nedovoljno zastupljene (temeljna tok- 
sikologija i nutricionizam); c) prisutno u samo nekoliko centara (upravljanje lancem prehrane) [46].

\section{ZAKLJUČAK}

U odnosu na druge industrijske sektore prehrambena industrija ima treći najveći multiplikativni učinak na output koji ostvaruje hrvatska ekonomija, što dodatno potvrđuje njezin strateški karakter. Prehrambena industrija pokazala je otpornost prema recesiji te u 2015., promatrano na godišnjoj razini, bilježi stopu rasta 4\%, povećanje proizvodnosti 5 - 6\% i izvoza 19\%, a ostvarila je i značajne regionalne akvizicije, prije svega koristeći komparativne prednosti kao što su tradicija u proizvodnji hrane i pića, prepoznatljivost brandova na regionalnom tržištu i dobra sirovinska osnova. [1,9,10,42,43]

S druge strane niska razina i višegodišnje smanjenje ulaganja u istraživanje i razvoj, slaba interakcija između $\mathrm{R} \& \mathrm{D}$, slaba povezanost s primarnom proizvodnjom, niska razina stranih investicija, niski apsorpcijski kapacitet i potražnja za inovacijama zbog tehnološke podinvestiranosti, niska produktivnost (70\% EU-28) koja je najvećim dijelom rezultat pasivnog restrukturiranja, a manjim dijelom inovacijskih aktivnosti koje, u više od $80 \%$ slučajeva, čine nabavke postrojenja, opreme i software-a - najveći su problemi hrvatske prehrambene industrije kao najveće grane prerađivačke industrije prema udjelu u BDV-u i broju zaposlenih.

Hrvatskoj je potrebna reindustrijalizacija i razvoj prehrambene industrije temeljen na novim tehnologijama i inovacijama i proizvodnji koja je orijentirana prema većim tržištima i izvozu, ali i prema turističkoj potražnji te boljem korištenju sirovinskog potencijala (poljoprivredne proizvodnje). Za povećanje konkurentnosti hrvatske prehrambene industrije temeljene na tehnološkim, organizacijskim i marketinškim inovacijama, uz korištenje postojećih komparativnih prednosti (tradicija, poljoprivredna proizvodnja, turistička potražnja) ključna je uloga države koja u narednom razdoblju treba znatno povećati ulaganja u $R \& D$, poreznim olakšicama i izravnim mjerama poticati razvojna istraživanja i interakciju $R \& D$, osigurati efikasniju koordinaciju $R \& D$ institucija i industrije i difuziju inovacija (npr. osnivanjem državne uprave za inovacije), poticati investiranje i poboljšati investicijsko okruženje te u suradnji s industrijom - promjenama $\mathrm{u}$ obrazovnom sustavu povećati apsorpcijski kapacitet za inovacije.

\section{Literatura}

[1] Kovačević, D.: Komercijalizacija znanstvenih istraživanja u funkciji gospodarske konkurentnosti Hrvatske. Proceedings of $13^{\text {th }}$ Ružička days Today science - tomorrow industry, Šubarić, D. (ed.), Osijek, Facuty of Food Technology Osijek, Croatian Society of Chemical Engineers (HDKI), (2011) 26-47. 
[2] Jovanović, I., Eškinja (2008.): Neki aspekti neoliberalizma u svjetskom gospodarstvu. Zbornik Pravnog fakulteta Sveučilišta u Rijeci. 29 (2) 941-958.

[3] Stiglitz, J. E. (2004.): Globalizacija i dvojbe koje izaziva. Algoritam, Zagreb.

[4] Kovačević, D. (2003.): Hrvatski gospodarski labirint. Prehrambeno-tehnološki fakultet Osijek. Osijek.

[5] Lovrinčević, Ž. (2009.): Tehnološka složenost te struktura ponude i potražnje industrijskih proizvoda u Hrvatskoj. Ekonomski pregled. 60 (11) 535-569.

[6] Teodorović, I., Buturac, G. (2006.): Perspektive industrijske proizvodnje u Hrvatskoj i intraindustrijska razmjena. Ekonomski pregled. 57 (11) 705-729.

[7] Hrvatski zavod za mirovinsko osiguranje (2017.). Novosti. http://www.mirovinsko.hr/UserDocsImages/publika cije/Novost-Newsletter/2017/HZMOnewsletter01_2017.pdf [pristupljeno 18. 3. 2017.]

[8] Wikipedija (2017.): Konkurentnost. https://hr.wikipedia.org/wiki/Konkurentnost [pristupljeno 18. 3. 2017.].

[9] Industrijska strategija Republike Hrvatske 2014. - 2020 (N.N. br. 126/2014.).

[10] Palić, P., Rašić-Bakarić, I. (2016.): Sektorske analize: Hrana i piće. Sektorske analize. Ekonomski institut. Zagreb. 5 (45).

[11] Kolaković, M. (2003.): Teorija intelektualnog kapitala. Ekonomski pregled. 54 (11-12) $925-$ 944.

[12] Kolaković , M. (2010.): Virtualna ekonomija. Strategija d.o.o. Zagreb. Zagreb.

[13] Thurow, L. C. (1997.): Budućnost Kapitalizma. Mate d.o.o. Zagreb, Zagreb.

[14] Sundać, D., Fatur, I. (2004.): Intelektualni kapital - čimbenik stvaranja konkurentskih prednosti i logističkih poduzeća. Ekonomski pregled. 55 (1-2). 85-96.

[15] Sundać, D., Švast, N. (2009.): Intelektualni kapital - temeljni čimbenik konkurentnosti poduzeća, Ministarstvo gospodarstva, rada i poduzetništva. Zagreb.

[16] Zelenika, R., Pupovac, D. (2001.): Intelektualni kapital - razvojni resurs logističkih kompanija za 21. stoljeće. Ekonomski pregled. 52 (9-10) 1034-1052.

[17] Strategija poticanja inovacija Republike Hrvatske 2014. - 2020 (N.N. br. 153/2014.).

[18] Strategija pametne specijalizacije (N.N. br. 32/2016.).

[19] Kotler, P. (2001.): Upravljanje marketingom. Mate d.o.o. Zagreb. Zagreb.

[20] Bečić, E., Dabić, M. (2008.): Analiza ulaganja poslovnog sektora Republike Hrvatske u istraživanje i razvoj. Revija za sociologiju. XXXIX (1-2) 69-84.

[21] Europska komisija (2014.): Obzor 2020. Okvirni program EU-a za istraživanje i inovacije. Luxembourg: Ured za publikacije Europske unije. https://ec.europa.eu/programmes/ horizon2020/sites/horizon2020/files/H2020_HR_KI0213413HRN.pdf [pristupljeno 19. 3. 2017.].

[22] European Commission (1995): Green Paper on Innovation. Luxembourg: Office for Official Publications of the European Communities. http://europa.eu/documents/comm/green_papers/pdf/com95_688_en.pdf[pristupljeno 19.3.2017.]. 
[23] European Commission (1996): The First Action Plan for Innovation in Europe. Innovation for growth and employment. Luxembourg: Office for Official Publications of the European Communities. http://aei.pitt.edu/ 5589/1/5589.pdf [pristupljeno 19. 3. 2017.].

[24] European Council, 2000. Presidency Conclusions. Lisbon European Council, March 2000. http://www. europarl.europa.eu/summits/lis1_en.htm [pristupljeno 19. 3. 2017.].

[25] Boromisa, A-M., Samardžija, V. (2006.): Hrvatska i Lisabonska strategija: približavanje ciljeva. U: Pridruživanje Hrvatske Europskoj uniji - izazovi sudjelovanja. Ott, K. (ur.). Zagreb: Institut za javne financije: Zaklada Friedrich Ebert. 199-226. http://www.ijf.hr/Eu4/ boromisa-samardzija.pdf [pristupljeno 19. 3. 2017.].

[26] European Council, 2002. Presidency Conclusions. Barcelona. 15 and 16 March 2002. http:// ec.europa.eu/ invest-in-research/pdf/download_en/barcelona_european_council.pdf [pristupljeno 19. 3. 2017.].

[27] European Commission (2005): More Research and Innovation - Investing for Growth and Employment: A Common Approach. http://ec.europa.eu/invest-in-research/pdf/download_ en/comm_native_com_2005_0488_4_en_acte.pdf [pristupljeno 19.3. 2017.].

[28] European Commission (2002): The Sixth Framework Programme covers Community activities in the field of research, technological development and demonstration (RTD) for the period 2002 to 2006. https://ec.europa.eu research/fp6/pdf/fp6-in-brief_en.pdf [pristupljeno 19. 3. 2017.].

[29] European Commission (2007): 7 th Framework Programme for Research and Technological Development. https://ec.europa.eu/research/fp7/index_en.cfm [pristupljeno 19. 3. 2017.].

[30] European Commission (2014): Europe 2020 strategy. https://ec.europa.eu/info/strategy/european-semester/framework/europe-2020-strategy_en [pristupljeno 19. 3. 2017.].

[31] Vlada Republike Hrvatske (2016.): Nacionalni program reformi 2016. http://ec.europa.eu/ europe2020/pdf/csr2016/nrp2016_croatia_hr.pdf [pristupljeno 19. 3. 2017.].

[32] Aralica, Z. (2013.): Sektorske analize: Hrana i piće. Sektorske analize. Ekonomski institut, Zagreb. 2 (22).

[33] Ministarstvo znanosti, obrazovanja i sporta (2014.): Plan razvoja istraživačke i inovacijske infrastrukture u Republici Hrvatskoj.

[34] Ministarstvo regionalnoga razvoja i fondova Europske unije (2014.): Operativni program: Konkurentnost i kohezija 2014. - 2020. http://www.strukturnifondovi.hr/UserDocsImages/ Documents/01\%20OPKK\%202014-2020\%20hrv\%2027112014.pdf [pristupljeno 19. 3. 2017.].

[35] Eurostat, 2016. http://ec.europa.eu/eurostat/web/conferences/conf-2016 [pristupljeno 19. 8. 2016.].

[36] European Commission (2015): The 2015 EU Industrial R\&D Investment Scoreboard. http:// iri.jrc.ec.europa. eu/scoreboard15.html [pristupljeno 19. 3. 2017.].

[37] European Commission (2016): European Innovation Scoreboard 2016. http://ec.europa.eu/ growth/industry/innovation/facts-figures/scoreboards_hr [pristupljeno 19. 3. 2017.].

[38] European patent office, 2015.

[39] Državni zavod za intelektualno vlasništvo (2014.): Minivodič za poslovnu zajednicu. Intelektualnim vlasništvom do uspješnog poslovanja. 
[40] The Global Competitiveness Report 2016-2017. Schwab, K. (ed.). World Economic Forum. Geneva.

[41] Državni zavod za intelektualno vlasništvo (rujan, 2016), Registri patenta, žigova i industrijskog dizajna.

[42] Buturac, G., Vizek, M. (2014.): Makroekonomska analiza izvozne konkurentnosti prehrambene industrije Republike Hrvatske. Ekonomski institut, Zagreb.

[43] Buturac, G., Vizek, M. (2015.): Izvoz prehrambene industrije i učinci na gospodarstvo: slučaj Hrvatske. Ekonomski pregled. 66 (3) 203-230.

[44] FoodDrinkEurope (2016): European Food And Drink Industry, 2014-2015. European Food And Drink Industry, 2014-2015.http://www.fooddrinkeurope.eu/uploads/publications_documents/Data_and_Trends_2014-20151.pdf [pristupljeno 19.3.2017.].

[45] European Commission (2016): The competitive position of the European food and drink industry. https:// euroalert.net/publication/487/the-competitive-position-of-the-europeanfood-and-drink-industry [pristupljeno 19. 3. 2017.].

[46] European Technology Platform on Food for Life. Strategic Research Agenda 2007-2020. (2013-2020 and Beyond) Executive Summary. http://www.fooddrinkeurope.eu/uploads/publications_documents/SRIA_Executive_Summary_web_pdf [pristupljeno 19.3.2017.]. 


\section{INNOVATION AS FOUNDATION FOR THE COMPETITIVENESS OF THE CROATIAN FOOD INDUSTRY}

\section{Summary}

When looking at success in innovation (Summary Innovation Index (SII)), which is based on 25 indicators, including human resources, successfulness of the research system, investments by private and public sectors in research and development (R\&D), intellectual property (brands, patents, industrial design), and economic effects (exports, employment) Croatia was at the bottom of the EU list in 2015, i.e. the results of success in innovation were at half of the EU-28 average and 2 or 3 times lower than the results accomplished by the leaders in innovation: Sweden, Finland, Denmark, Germany, and the Netherlands. In contrast to the trend of an increased percentage share of R\&D in GDP of the EU and the EU innovation policies declared in the Lisbon Strategy (2000), the conclusions of the Barcelona European Council (2002), and Horizon 2020, aimed at resolving the problems caused by the so called "European Paradox" and insufficient investment, especially by the private sector, in R\&D and in strengthening the interaction between science and the economy, according to the example set by economic leaders Japan and the USA - there were several years of continuous decrease in R\&D investments, which resulted in Croatia's position at only $1 / 3$ of the EU average, with $0.76 \%$ of GDP dedicated to R\&D. The mentioned low levels and years of reductions in $R \& D$ investments, low interaction between R\&D, insufficient connectivity with primary production, low levels of foreign investments, low absorption capacity, the demand for innovation due to insufficient investments in technology, and the reduction in the share of HT and MHT industries - are the most serious problems of the Croatian processing industry, including the food processing industry as its largest part (according to its GVA). The food industry demonstrated its resistance to recession in 2015; at the yearly level, it had a growth rate of $4 \%$, increase in productivity of $5-6 \%$ and in exports of $19 \%$, and it made significant regional acquisitions, mostly by using the advantages like tradition in food and beverage production, brand recognition on the regional market, and good raw material base. On the other hand, productivity is still at $70 \%$ of the EU average and it is mostly the consequence of passive restructuring, and to a lesser extent, the result of innovation activities, which, in more than $80 \%$ of the cases, include acquisitions of facilities, equipment, and software. Croatia needs re-industrialisation and the development of food industry based on new technologies and innovations, and on the production oriented at larger markets and exports, but also at tourism demand and at better utilisation of raw material potentials (agricultural production). In order to increase 
the competitiveness of the Croatian food industry, based on technological, organisational, and marketing innovations, by using the existing comparative advantages (tradition, agricultural production, tourism demand), the state must play a key role by significantly increasing investments in R\&D, introducing tax breaks and direct measures to incentivise developmental research and $R \& D$ interaction, ensuring more efficient $R \& D$ coordination in institutions and industry, and the diffusion of innovation (e.g. by forming a state run Innovation Administration), incentivising investments and improving the investment environment, and in cooperation with the industry - introducing changes in the education system to increase the absorption capacity for innovation.

Keywords: food industry; competitiveness; research and development; innovation

\section{Dragan Kovačević}

Prehrambeno-tehnološki fakultet Osijek

Sveučilište J. J. Strossmayera u Osijeku

F. Kuhača 20, 31000 Osijek, Hrvatska 